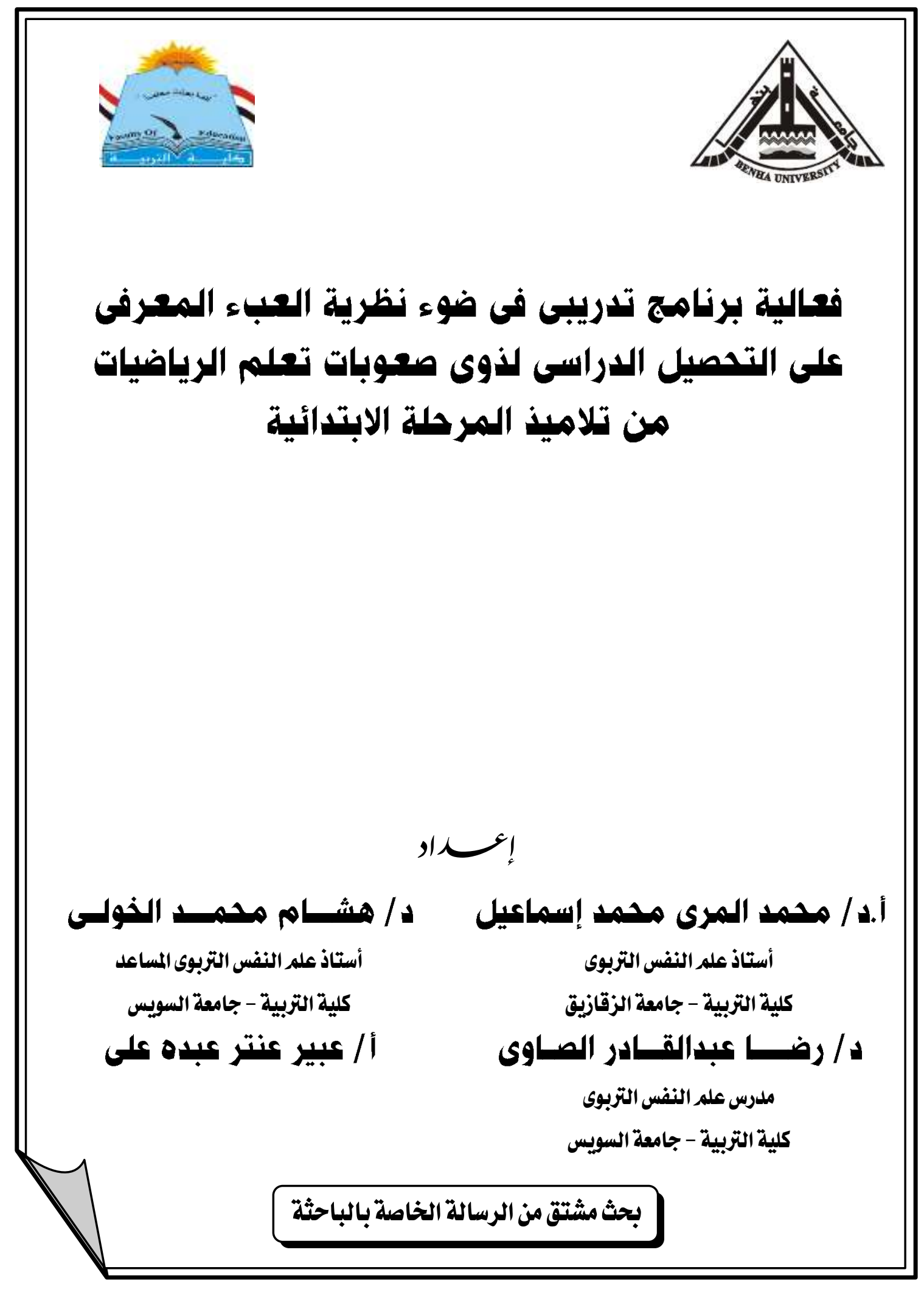




\section{فعالية برنامج تدريبى فى ضوء نظرية العباء المعرفى على التصصيل الدراسى لذوى صعوبات تعلم الرياضيات من تلاميذ المرحلة الابتدائية} ! إنـ

ل الـ / هشام محمد الخولي أستاذ عله النفس التزبوي المساعد كلية التربية - جامعة السويس

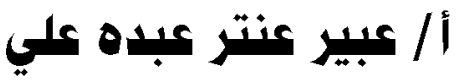

أ.د / محمد المري محمد اسماعيل أستاذ علم النفس التربوي كلية التربية - جامعة الزقازيق هـ / رضا كبدالقادر الصاوي ملدرس عله النفس التربوي كلية التربية - جامعة السويس

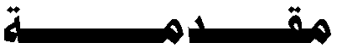

يُعد التحصيل الدراسـى أحد أهم المتغيرات النفسية والمعرفية التى تثـغل بال الكثير مـن علماء النفس والتربية نظراً لما يتمتع به هذا المتغير من أهمية لدى الآباء والمعلمين والقائمين على العملية التعليمية، ولذا يعد الكثف عن العوامل الميسرة والمعيقه لله مطلباً ملحاً، ويوجزهـا السيد

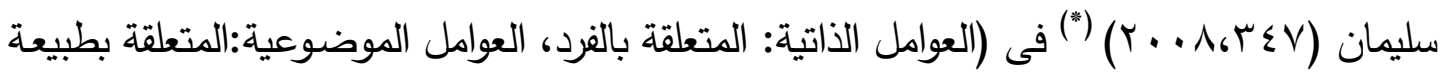
المادة، العوامل الوسيطة:المتعلقة بالمتغيرات البيئية وأسلوب العرض) تُعتبـر صـعوبات التعلم أهـم العوامـل الذاتيـة التى تقفـ وراء تـدنى مسـتوى التحصـيل الدراسى فى المراحل التعليمية المختلفة وخاصة لدى تلاميذ المرحلة الابتدائية حيث تتراوح نسبة انتشـارها بيـن ( 7 (: . ץ \%)، وتُعد صـوبات تعلم الرياضـيات أكثر أنمـاط صسوبات التعلم شيوعاً وانتشـاراً بين تلاميذ المرحلـة الابتدائية، وأقلها فى الحصـول على برامج علاجيـة فعالـة

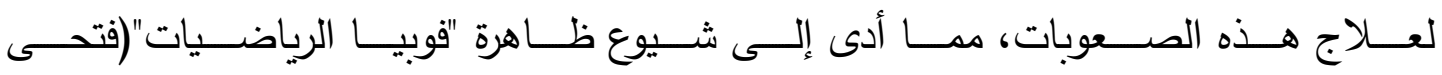

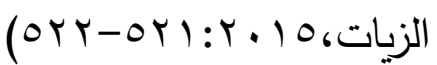
يذكر (Vanloon-Hillen etal., 2012:130) أن صعوبات التعلم تظهر فى عجز التلاميذ عن تطبيق الاستراتيجيات الملائمسة للعمليـة الحسابية نتيجة استخدامهم لاستراتيجيات (A.P.A) American Psychological Association يتبع البحث الحالى في التوثيق نظام الجمعية الأمريكية لعلم النفس (2)

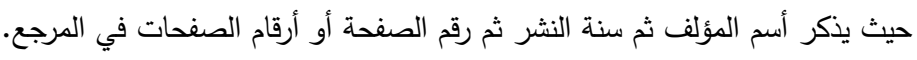


مفككه غير ناضجة ليست هرمية أو تراكمية بطبيعتها تتشأ نتيجه لتجاهل المعلمين لتحليل الأخطاء فى أداء التلاميذ وتزويدهم بالتغذية الراجعة أو لعرضهم محتوى الرياضيات بأساليب

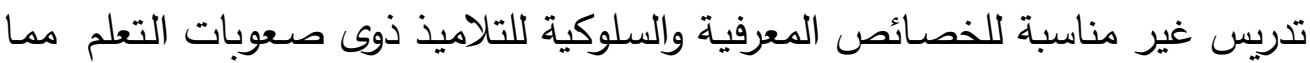
يزيد من العبء الواقع على الذاكرة العاملة المحدودة السعة ويزيد تحميلها بكمية كبيرة من

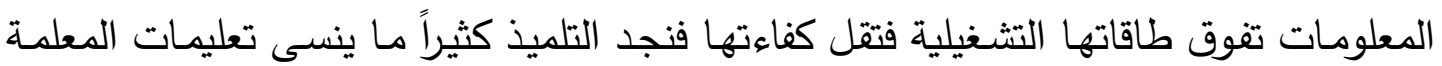
ويواجه صعوبات فى الاستمرار فى المهام والأنثطة ويصرف انتباهه بسهولة مما يترتب عليه انخفاض التحصيل الدراسى له ويجعل الرياضيات أكثر المواد الدراسية كرهاً لديهم ويساهم فى الدى

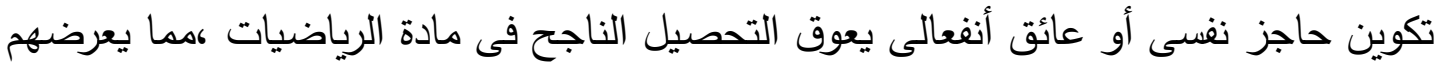
للاحباطات المتكررة نتيجه لفثلهم الدراسى والرفض الاجتماعى من قبل الآخرين وكلها عوامل

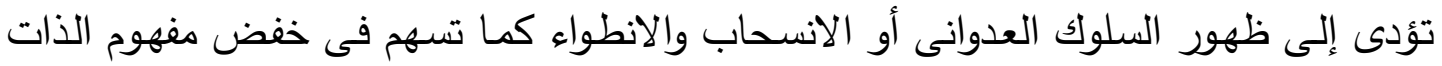

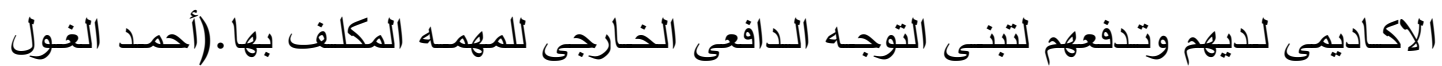
$\left(19-1 \Lambda: r \cdot 1 r_{6}\right.$

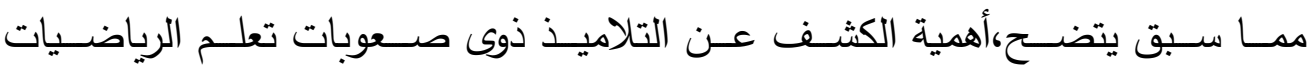

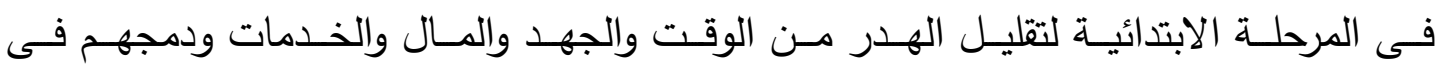

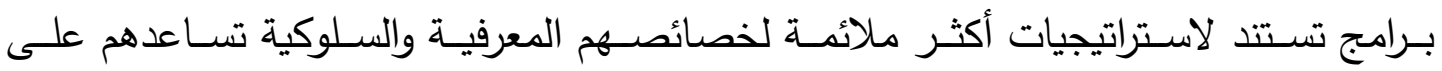

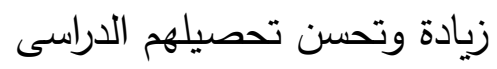

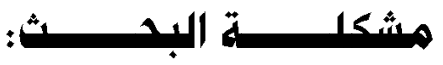

فـى ظـل هـذه المعـدلات المرتفعـة لانتثــار صـعوبات الـتعلم بـين تلاميـذ المرحلــة

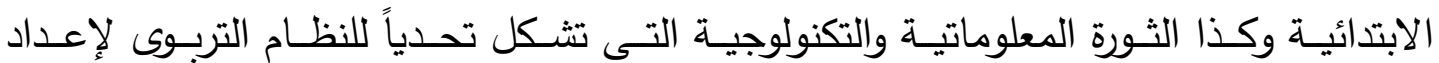

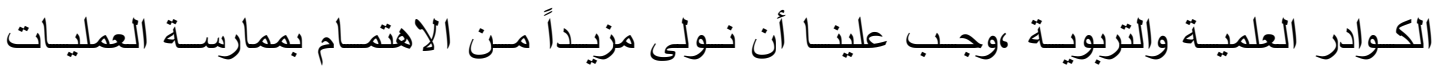

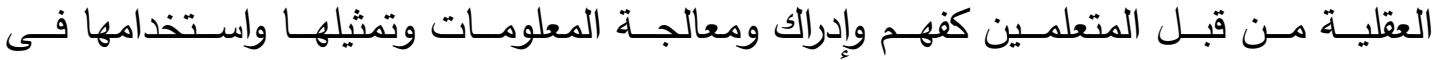

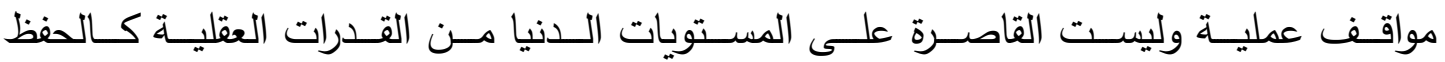

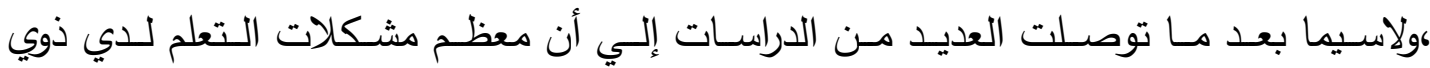

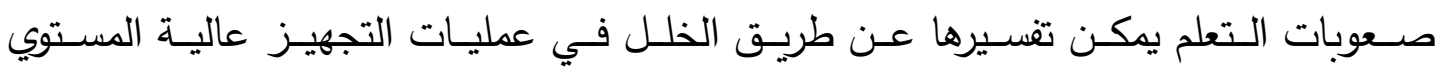

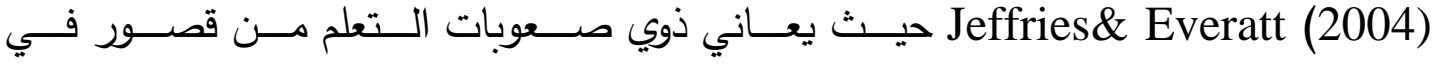

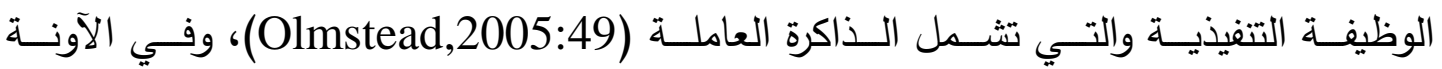


الأخيـرة أصــبحت الـذاكرة العاملــة الأسـاس للعديـد مـن الدراســات التـي تجـري علـي ذوي

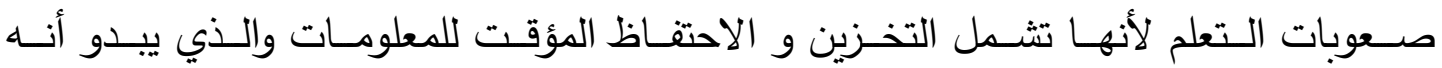

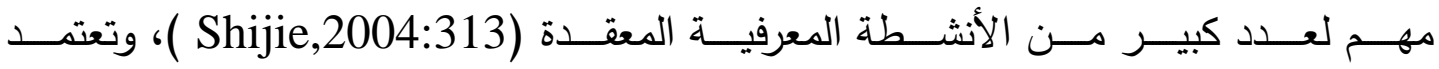

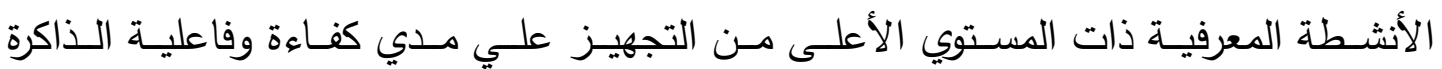

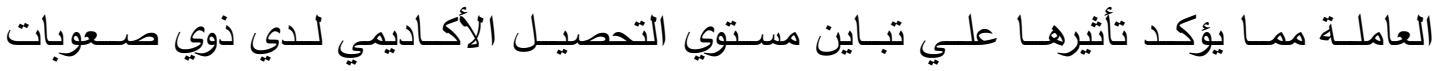
التعلم ولدي العاديين ( Swanson,1990:59)

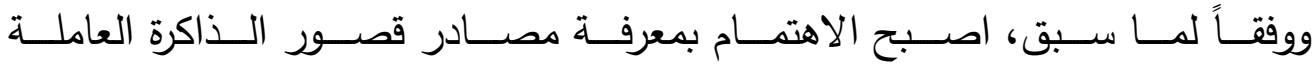

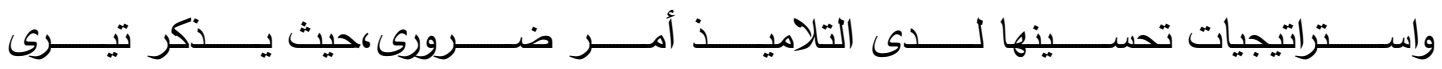
Terry $(2006,103)$ هى سعة الذاكرة،استراتيجيات الذاكرة،والمعلومات المكتسبة.

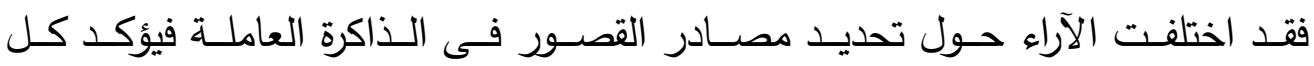

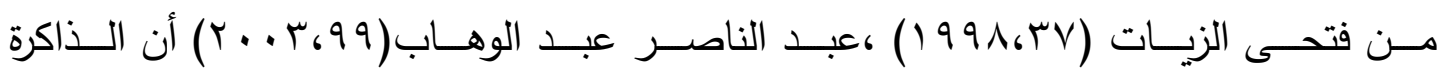

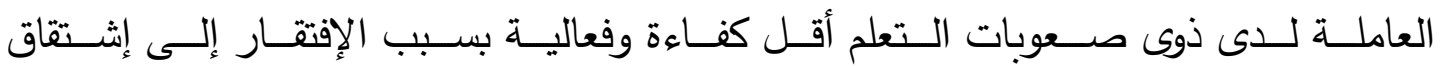

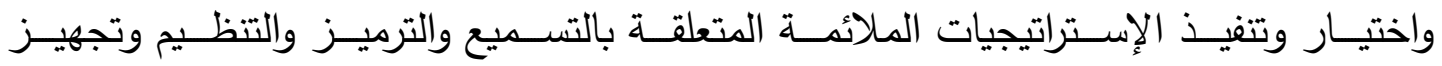

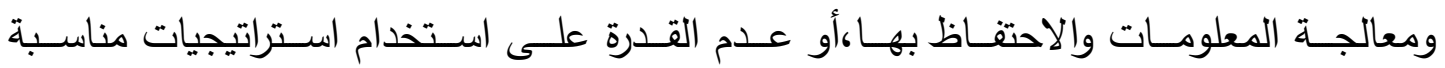

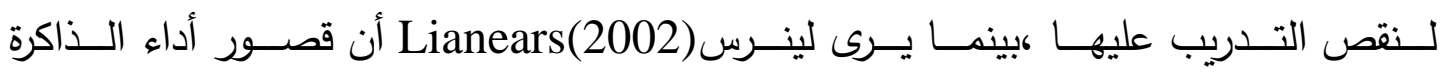

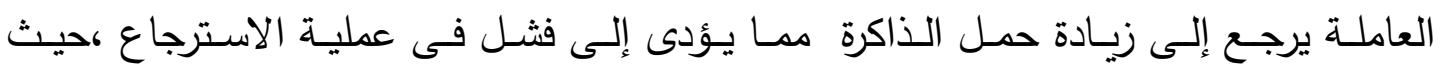

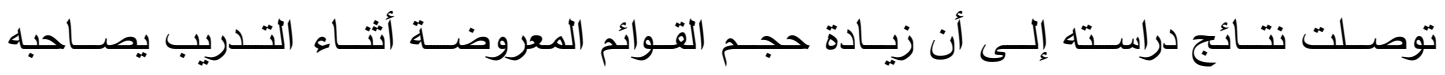

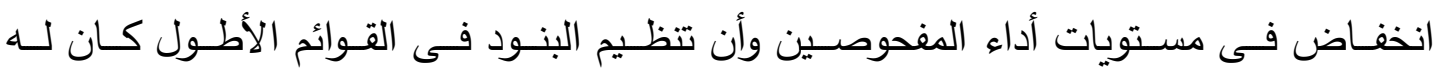

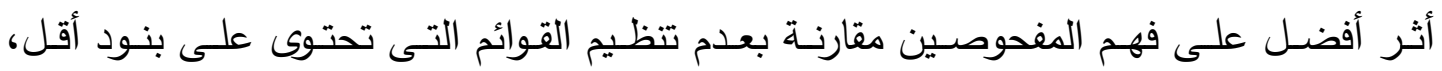
ويذكر (2015:7, Jeffrey \& Ian ) أنه يكون لدي الأطفال استعداد للتنمية والتقدم

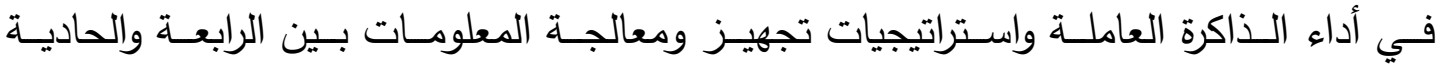

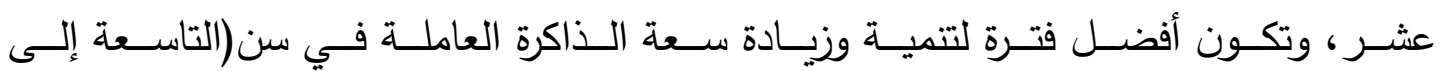
الحادية عشرة) حيث يمكن أن تصل إلي ضعفين أو ثلاثة أضعاف في سن الرابعة.

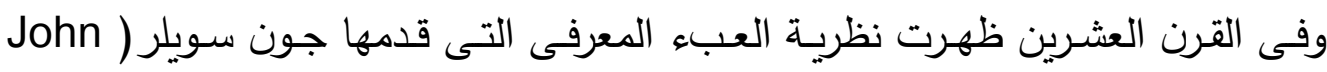
(Sweller

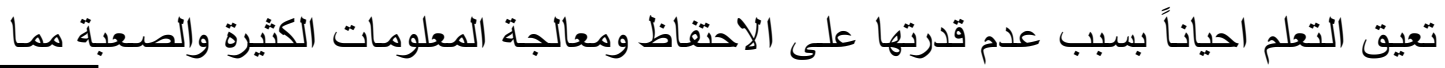


يتطلب تعليم استراتيجيات تعلم وتعليم تساعد على مواجهة هذه المحدودية وتعمل على تخفيف

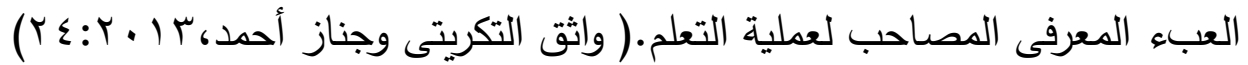

والبحث الحالى محاولة لزيادة وتحسن التحصيل الدراسي في مادة الرياضيات من خلال

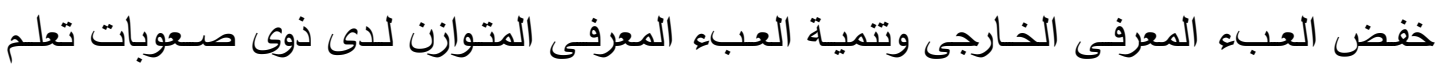
الرياضيات من تلاميذ الصف الرابع بالمرحلة الابتدائية، وعلى هذا يمكنتا طرح الأسئلة الأتية:

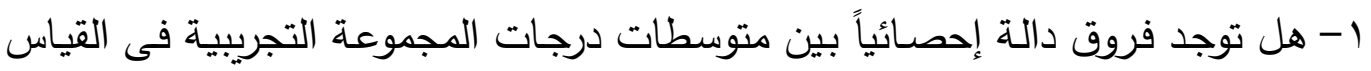

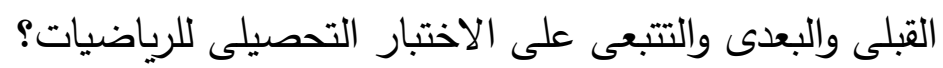

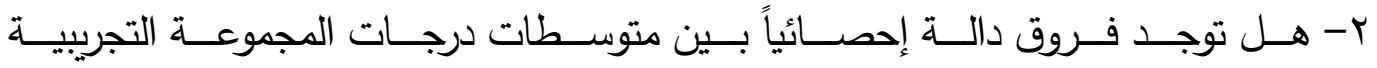
والمجموعـة الضــابطه فـى القيـاس البعـدى علـى الاختبــار التحصـيلى للرياضـيات لصالح المجموعة التجريبية؟

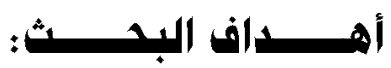

1-التحقق من فعالية برنـامج تدريبي مُعد فى ضـوء نظريـة العبء المعرفى على زيـادة وتحسن التحصيل الدراسى لذوى صعوبات تعلم الرياضيات من تلاميذ الصف الرابع

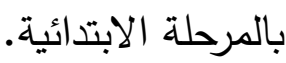
ץ-الكثف عن أفضل المهارات والاستراتيجيات العلاجية لنظريـة العبء المعرفى والتىى لإنى

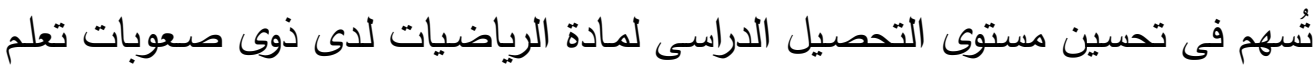
الرياضيات من تلاميذ الصف الرابع بالمرحلة الابتدائية.

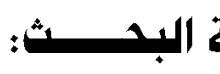

1- التصــى لدراســة العـبء المعرفى وأثخره على سـعة الـذاكرة العاملـة، والـذى يعتبـر

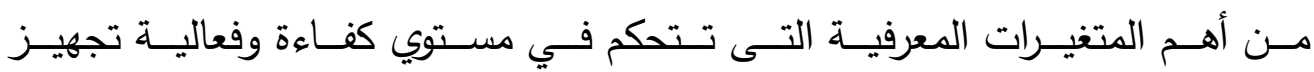
المعلومات وتخزينها واسترجاعها.

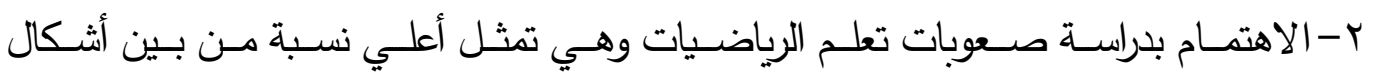

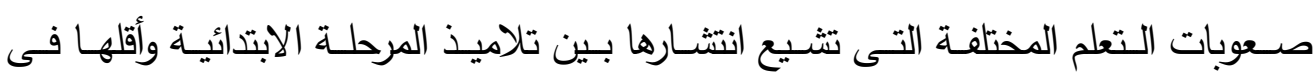

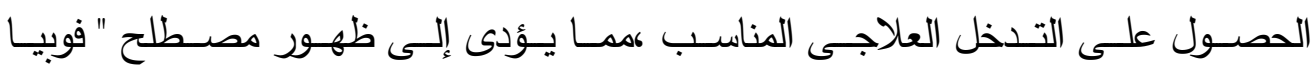

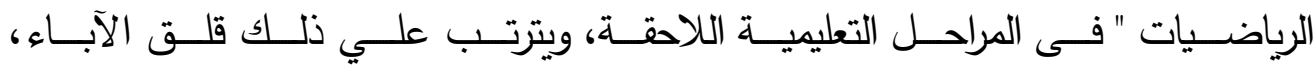
والمعلمين، والمهتمين بتربية وتعليم التلاميذ. 
r- إثراء مجال البحث بما يزود بـه المكتبة العربية من مقاييس واختبارات وبرنامج خاص

بذوى صعوبات تعلم الرياضيات من تلاميذ المرحلة الابتدائية.

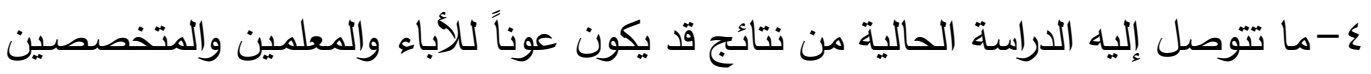

فى مجال رعايه التلاميذ ذوى صعوبات تعلم الرياضيات،من خلال تزويدهم بالمعلومات

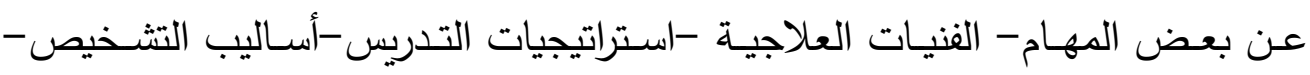

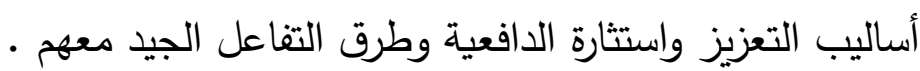

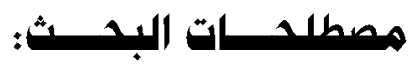

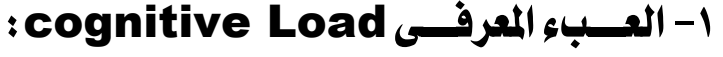

يُعرفهـ سويلر وشيدلر Sweller \& Chadler (1991) على أنـه الكميـة الكليـة

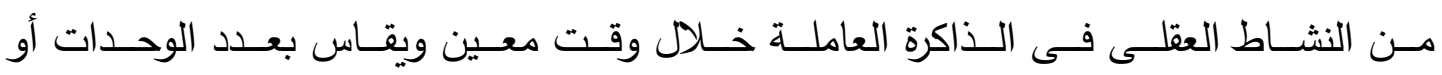

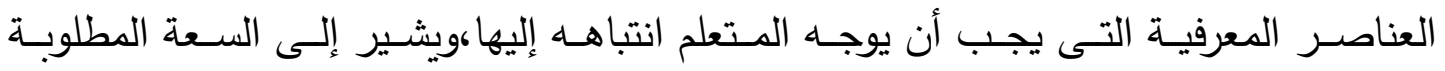

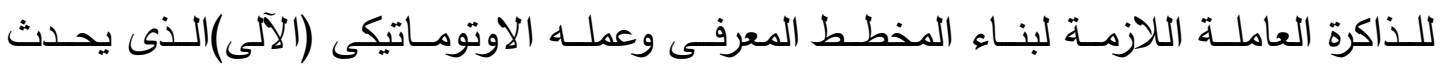

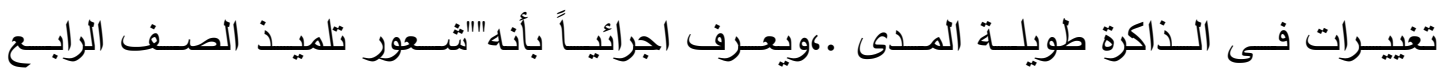

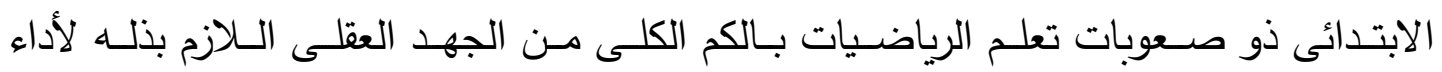

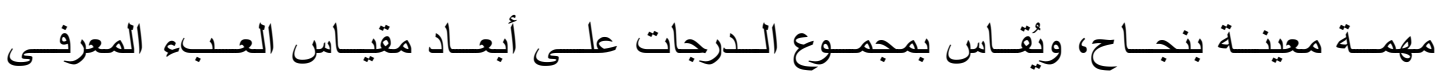
الحالى" ،والذى يشمل الأبعاد الثلاثة التالية:

\section{أ) العب ء المعرفى الفارجs Extraneous Load}

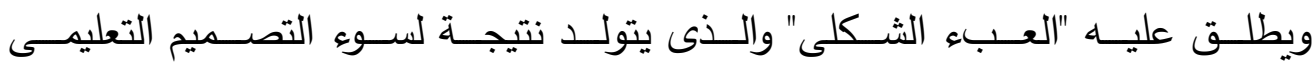
والأساليب التدريسية غير المناسبة، والتى تؤدى إلى إهدار الكثير من الوقت والجهد.

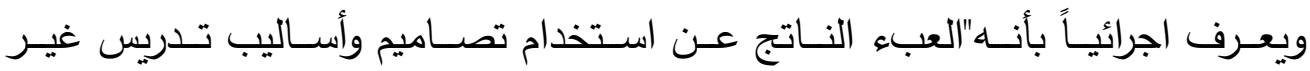

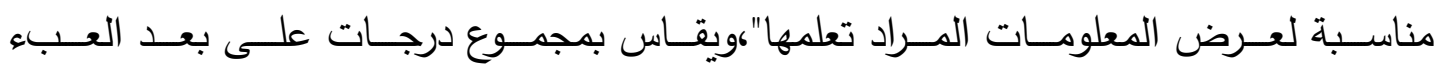
الخارجى من مقياس العبء المعرفى (إعداد/الباحثة)

\section{ب) العب اء المعرفى الداخلى Intrinsic Load:}

ويطلق عليه "العبء الجوهرى" وهو الجهد الذى ينتج عن الطبيعة المعقدة للمعلومات

مرتفعة التفاعل التى يجب معالجتها والإبقاء عليها فى وقت واحد فى الذاكرة العاملة. 
ويعرف اجرائياً بأنه "العبء الناتج عن صعوبة المادة المراد تعلمها نتيجة لكثرة العناصر

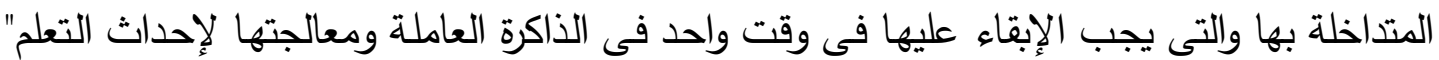
ويقاس بمجموع الدرجات على بعد العبء الداخلى من مقياس العبء المعرفى (إعداد الباحثة.

\section{ج) العبء المعر فى المتوازن (وثيق الصلة) Germane Load:}

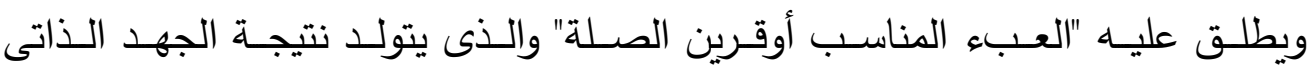

للمتعلم لمعالجة المعلومات التى تؤدى لبناء المخطط المعرفى له أثناء عملية التعلم.

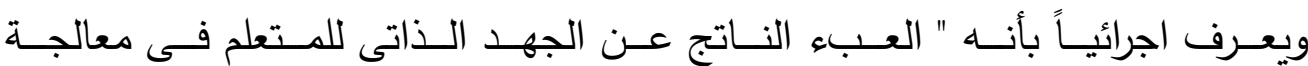

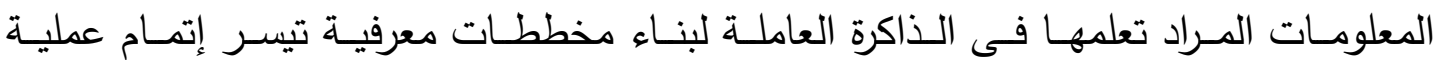

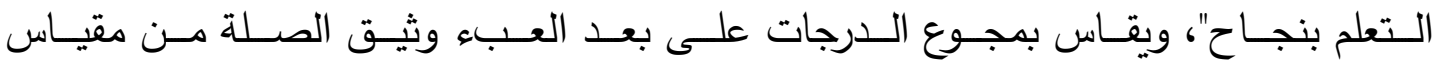
العبء المعرفى( إعداد / الباحثة)

\section{بcademic Achievement التحصيـل الدراســيـ}

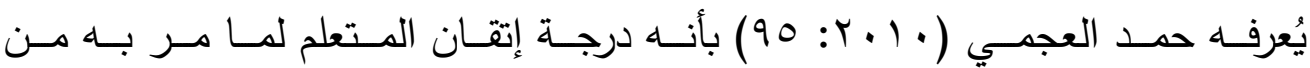

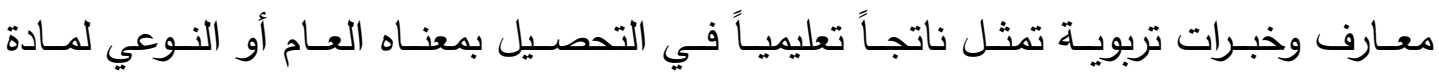

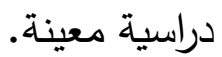

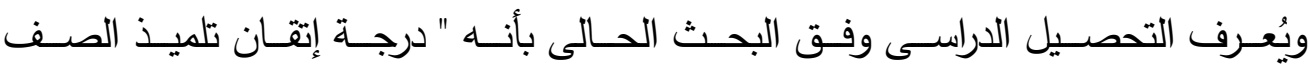

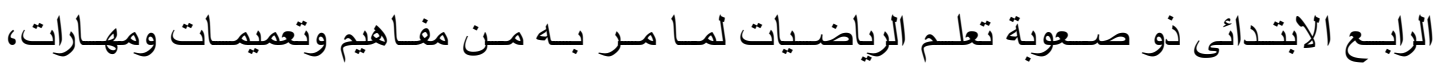
ويُقاس بمجموع درجاته على الاختبار التحصيلى الكلى للرياضيات ( إعداد/ الباحثة)

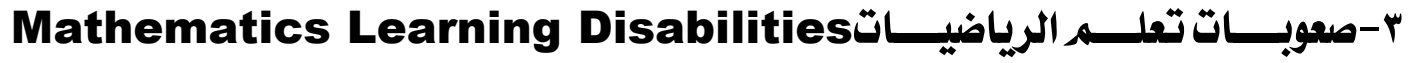
هى مصطلح يعبر عن عسر أو صعوبات فى:

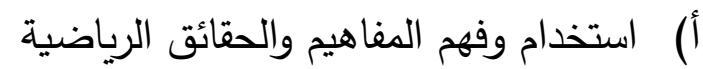
ب) بالفهم الحسابى والاستد لال العددى والرياضى.

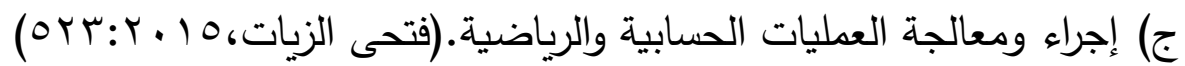

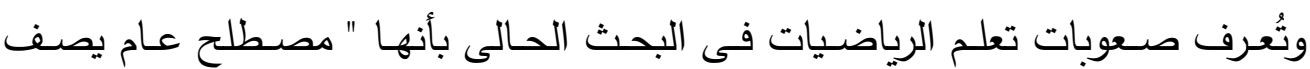

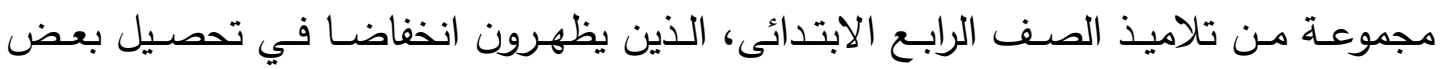

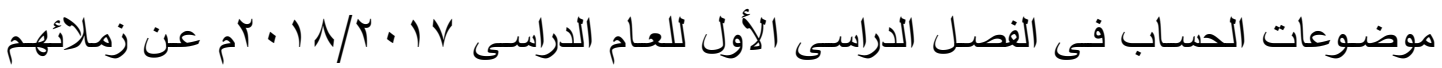


العاديين وفقاً لدرجاتهم على الاختبار التحصيلى للرياضيات(إعداد/ الباحثة) مع أنهم يتمتعون

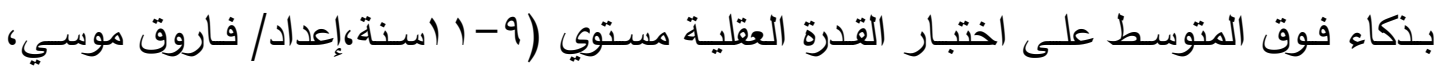

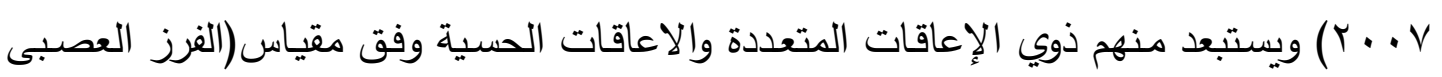

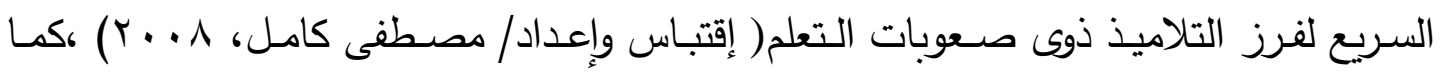
يعانون من ارتفاع العبء الخارجى وانخفاض العبء وثيق الصلة وفق مقياس العبء المعرفى (إعداد/ الباحثة).

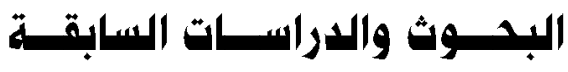 أولاً: دراسات خاصة بالعبيء المعرفى}

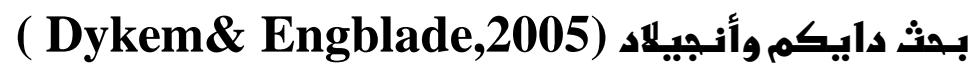

هدف إلى بيان دور الإطناب والخبرة فى صنع قرار المجموعة والإسترجاع لاى ( • ب)

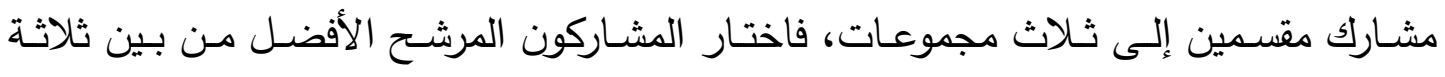
مرشحين لرئاسة مجلس الطلبة من كل مجموعة، وطلب من أفراد المجموعات استرجاع أكبر

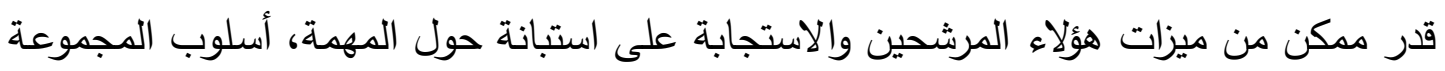

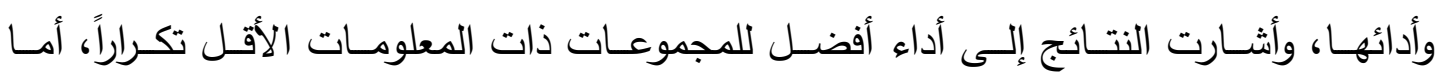
المجموعات ذات المعلومات الأكثر تكراراً فكان استرجاعها أقل.

دراسة عادل البنا(^••(1)

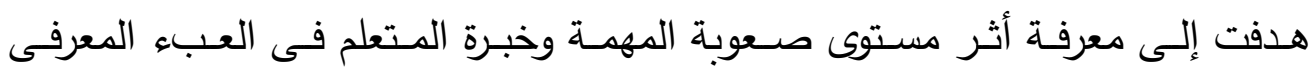
المصاحب لحل المشكلات، وطبق الباحث مقياس ناسا (Nassa Tlex, 2005) للعبء

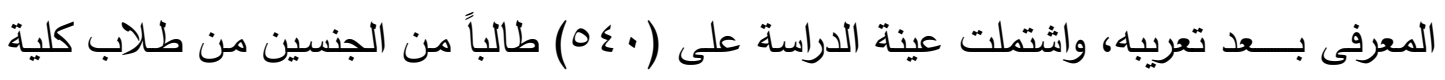
التربية بدمنهور بجامعة الإسكندرية، وقد توصلت النتائج إلى وجود فروق ذات دلالة إحصائية فى انخفاض مستوى العب؟ المعرفى المصـاحب لحل المشكلات للاى عينـة الدراسـة لكلتـا الاستراتيجيتين (الهدف الحر، تحليل المعانى النهائية) بمتوسط أقل لصالح استراتيجية الهدف

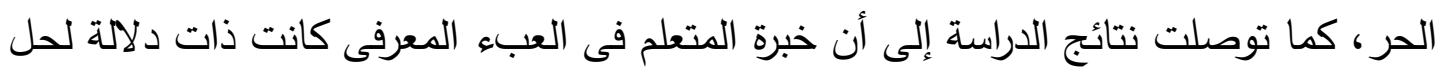
المشكلات المرتبطة بالعبء المعرفى. 


\section{دراسة وجند وهانز (Weigand \&Hanze,2009)}

التى أثبتت فاعلية استراتيجية الأمثلة المحلولة فى زيـادة العبء المعرفى وثيق الصلة بالموضوع وانخفاض مستوى العبء المعرفى الدخيل لدى (ع †) طالباً من طلبة المدرسة العليا لدراسة الفيزياء بألمانيا، كماتوصلت إلى وجود ارتباط سالب بين زيـادة العبء المعرفى والتقدير الذاتى للمتعلم، حيث استخدمت الدراسة اختبار تحصيلى لقياس العبء المعرفى ومقياس التقدير

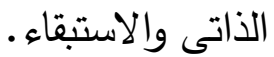

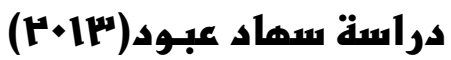
التـى هـدفت للتحقق مـن فاعليـة إسـتراتيجية الشـكلية المسـتندة إلى نظريـة العـبء المعرفي في التحصيل لمادة الكيمياء والتفكير العلمى لدى عينة مكونه من ( الطالبة (. (r) كمجوعة تجريبية،،( (r) كمجوعة ضـابطة) من طالبات الصف الأول متوسط في المدارس النهارية التابعة للمديرية العامة لتربية الكرخ الثالثة/ بغداد ،وبتطبيق أدوات الدراسة (الاختبار التحصيلى فى الكيمياء، اختبار التفكير العلىى) كشفت النتائج أن المجموعة التجريبية التي درست على وفق إستراتيجية الشكلية المستندة الى نظرية العبء المعرفي أفضل في التحصيل والتقكير العلمى عن المجموعة الضابطة التي درست وفق الطريقة الاعتيادية، مما يدل على أن هذه الطريقة ذو أثر ايجابي في التحصيل مادة الكيمياء لدى عينة الدراسة.

\section{دراسة وســـن هليـ(10)(10)}

التى هدفت إلى التحقق من أثر الايجـابى للتدريس وفق نظريـة العبء المعرفى فى تحصيل مـادة الكيمياء الحياتيـة واستبقاء المعلومـات والتـوير العلمى والتكنولوجى لدى ( • آ) طالب بقسم الكيمياء بكلية التربية جامعة بغداد حيث أظهرت النتائج وجود فروق دالة أحصائياً بتفوق طلاب المجموعة التجريبية على المجموعة الضابطة فى الاختبار التحصيلى.

\section{دراسة عبد الواهد مكى(11)}

التى هدفت للتعرف على فاعلية تصميم تعليمى -تعلمى قائم على نظريـة العبء المعرفى فى التحصيل والذكاء المكانى البصرى لــى (9ه) من طلاب الصف الثانى المتوسط مقسمين إلى مجموعتين،( • r) طالب كمجموعة تجريبية ، (Y) طالب كمجموعة ضابطة وأسفرت النتائج 
عن وجود فروق دالـة احصـائياً بين طلاب مجموعتى البحث (التجريبية والضـابطة) لصـالح المجموعة التجريبية فى الاختبار التحصيلى واختبار الذكاء الدكانى البصرى.

\section{ثانياً : دراسات خاصة بصعوبات التعله}

دراسة صوفيا جاموسر(r+1)

التى هدفت للتحقق من أثر استخدام استراتيجيات التنظيم الذاتى على تتمية مهارات حل

المشكلة الحسابية لدى (•r) تلميذ وتلميذة من ذوى صعوبات تعلم الحساب فى الحلقة الأولى القى

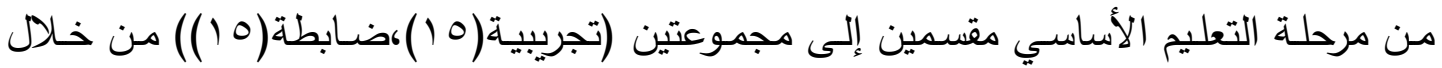

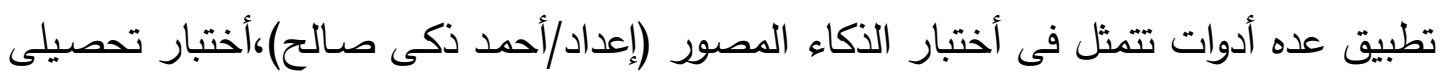

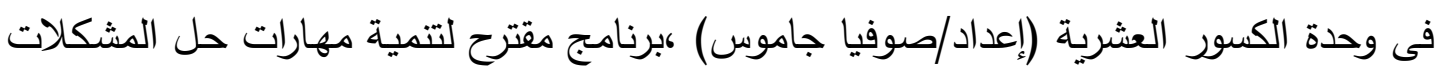

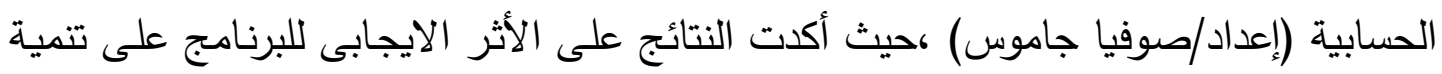
مهارات حل المشكلة الحسابية لاى تلاميذ العينة التجريبية .

دراسة (هشام بسيونسى (1)

التى هدفت للتحقق من فاعلية برنـامج وسـائط متعددة فى تتميـة المفاهيم الرياضية

لتلاميذ الصف الثالث الابتدائى ذوى صعوبات التعلم وإتجاهاتهم نحو الرياضيات على عينـة

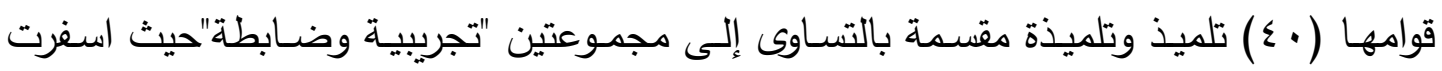

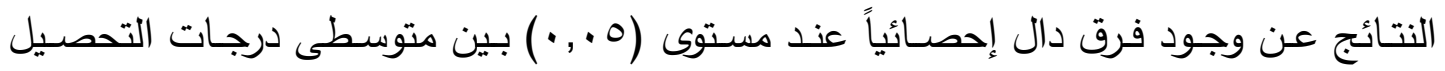

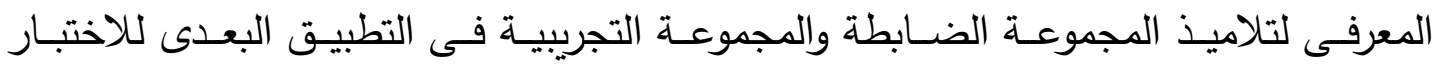

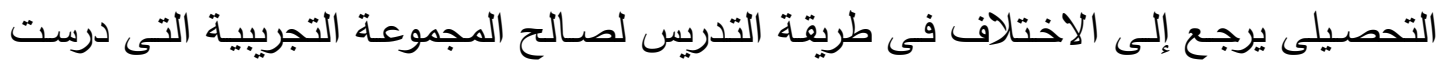
ببرنامج الوسائط المتعددة.

\section{دراسة ضحى السرر سعى (1) (r)}

التى هدفت للتحقق من أثر كثافة التفاصيل القليلة فى الرسومات المتحركة مقابل كثافة التفاصيل الكثيرة ببرامج الكمبيوتر التعليمية فى تتمية بعض المفاهيم الرياضية لاى ( • ؛ ) من

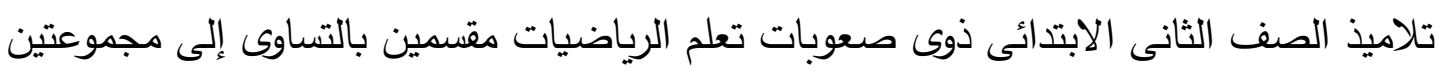

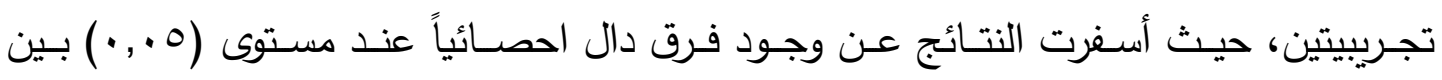


متوسطى درجات تلاميذ المجموعة التجريبية الأولى فى التطبيقين القبلى والبعدى فى اختبار التحصيل، والتى درست باستخدام الرسومات المتحركة قليلة التقاصيل وذلك لصالح التطبيق البعدى،كما أسفرت عن وجود فرق دال احصائياً عند مستوى (0. . •) بين متوسطى درجات تلاميذ المجموعة التجريبية الثانية فى التطبيقين القبلى والبعدى فى اختبار التحصيل، والتى

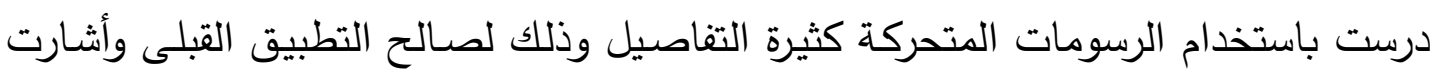
أيضا إلى وجود فرق دال احصائياً عند مستوى (0. ., ) بين متوسطى الرتب لدرجات تلاميذ

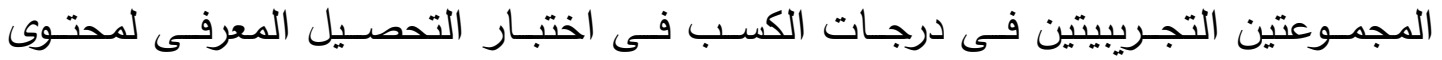
الرياضيات لدى تلاميذ الصف الثانى بالمرحلة الابتدائية ذوى صعوبات تعلم الرياضيات.

\section{دراسة زينب أبو العلا (r+11)}

التى هدفت للكثف عن أثر تتمية مهارات ماوراء الذاكرة " الوعى بسعة الذاكرة،التغذية الراجعة، المراقبة الذاتية) فى تحسين عادات الاستذكار وفاعلية الذات لدى (•r) تلميذ من ذوى صعوبات التعلم فى مرحلة الطفولة المتأخرة تتراوح أعمارهم من (9-1 (1) سنة مستخدمه الأدوات

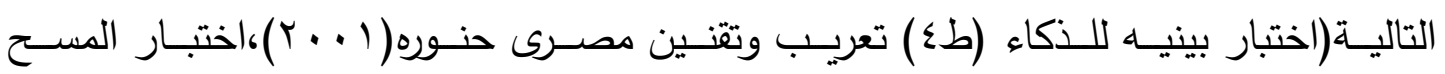

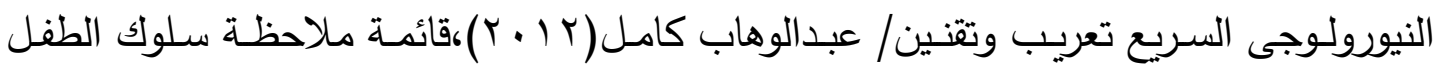

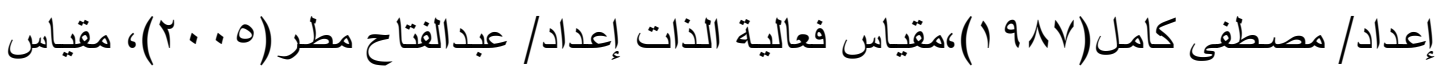
ماوراء الذاكرة ،البرنامج التدريبى إعداد/زينب أبو العلا)، وأسفرت النتائج عن وجود فروق دالة إحصائياً عند مستوى( ( . . ) بين متوسطى رتب درجات المجموعتين التجريبية والضابطة فى لهى القياس البعدى على كل من (مقياس عادات الأستذكار، مقياس مهارات ما وراء الذاكرة، مقياس لهاس فعالية الذات) لصالح المجموعة التجريبية.

\section{دراسة ظافى البيشى (11)}

التى هدفت للتحقق من فاعلية استخدام "أنشطة الحساب الذهنى " فى خفض صعوبات تعلم الرياضيات من تلاميذ المرحلة الابتدائية المتفوقين ذوى صعوبات التعلم لدى عينة قوامها قوامها (0) أطفال من المتفوقين عقليا ذوي صعوبات تعلم الرياضيات بالصف الرابع الابتدائى

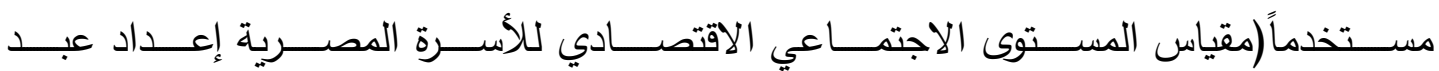




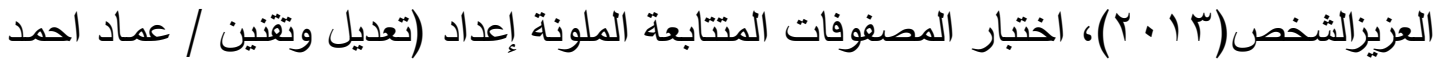

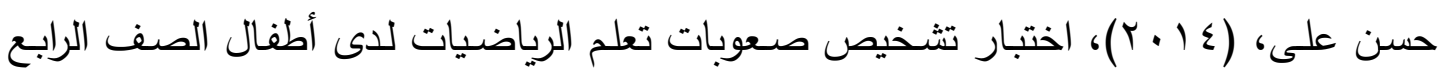

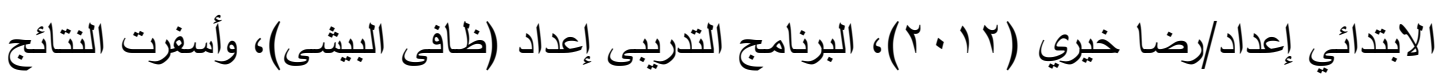

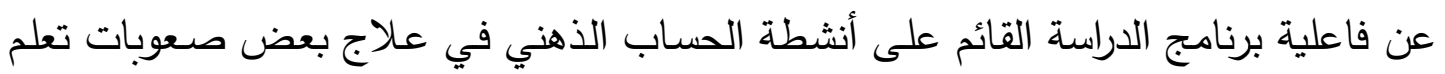
الرياضيات لدى الأطفال المتفوقين عقلياً.

\section{دراسة نيفين إسما عيل (1) (1)}

التى أكدت فاعلية تدريب الوظائف التتفيذية (الذاكرة العاملة، حل المشكلات، التخطيط) في علاج بعض صعوبات تعلم الرياضيات للى (· r) طفلاً وطفلة من ذوي صعوبات تعلم

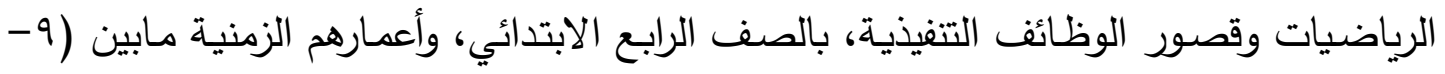

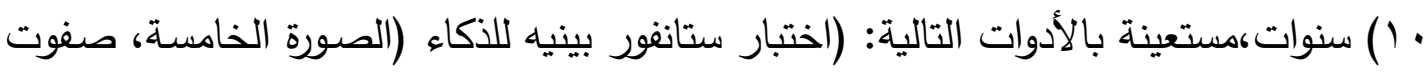

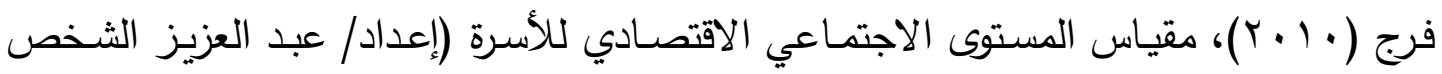

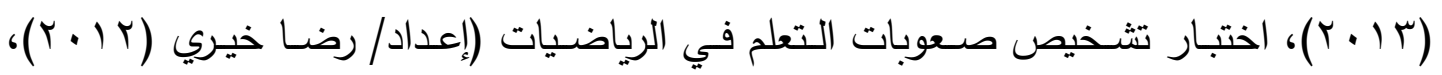
مقياس الوظائف التنفيذية (إعداد/ عبد العزيز الثخص وهيام فتحي (r (ب)، البرنامج التدريبي للوظائف التنفيذية لعلاج صعوبات تعلم الرياضيات. (إعداد/ تهاني منيب، دعاء زكي، نيفين

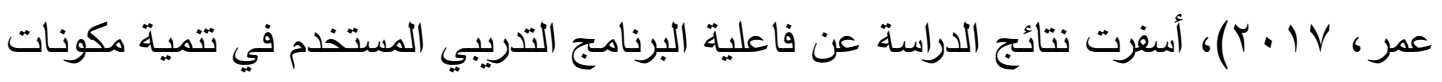
الوظائف التتفيذية لاى أطفال المجموعة التجريبية في علاج صعوبات التعلم .

\section{الفائدة من الدراسات السابقة}

استفادت الباحثة من الدراسات السابقة في معرفة حجم العينات المستخدمة والأدوات والوسائل الإحصائية، كما اطلعت الباحثة على ما توصلت إليه نتائج هذه الدراسات لغرض معرفة إذا كانت البحث الحالى تتقق أم تختلف مع نتائج هذه الدراسة.

\section{تعقبب على الدراسات السابقة}

من عرض الدراسات السابقة يتضح الآتى:

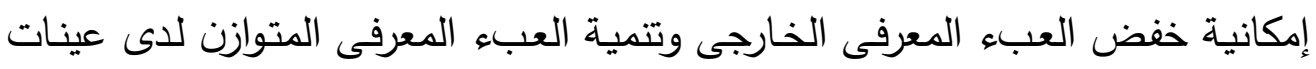

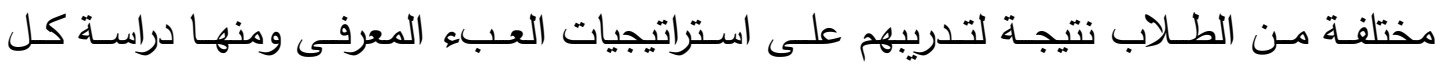




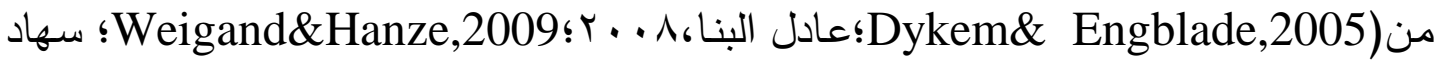

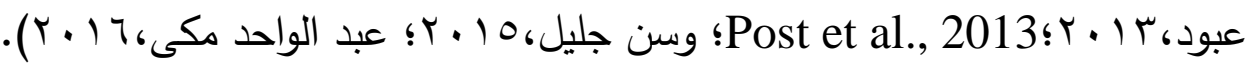

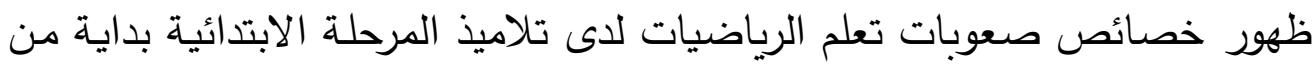

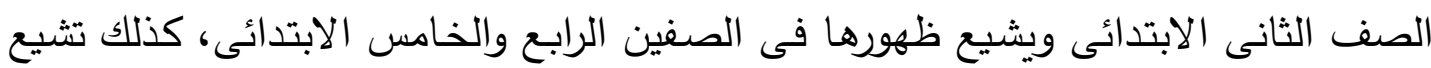
صعوبات تعلم الحساب أكثر من صعوبات تعلم الهندسة.

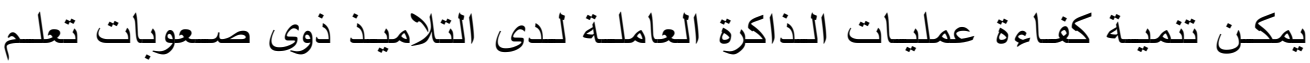
الرياضيات بداية من عمر 9 سنوات كما فى دراسة زينب أبو العلا (7 ( • Y).

في ضوء أهداف البحث وبنـاءً على تحليل أدبيات البحث، وما أسفرت عنه البحوث السابقة من نتائج، يمكن طرح فروض البحث الحالى، كما يلى:

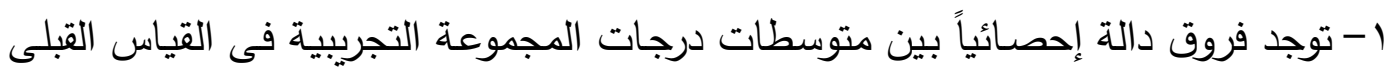
والبعدى والتتبعى على الاختبار التحصيلى للرياضيات .

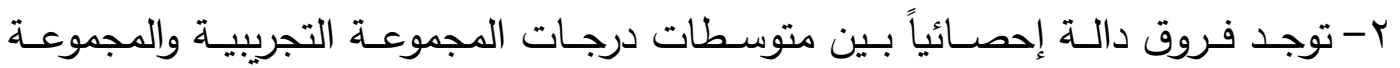

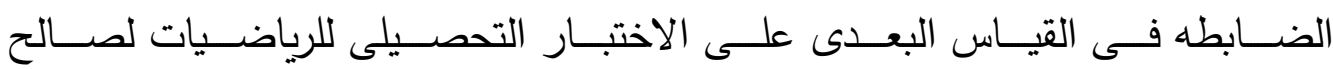

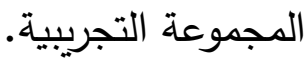
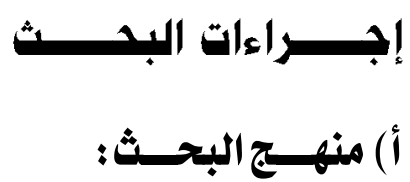

أعتمد البحث الحالى على المنهج التجريبي بالاعتماد على تصميم المجموعات المتكافئة ذو

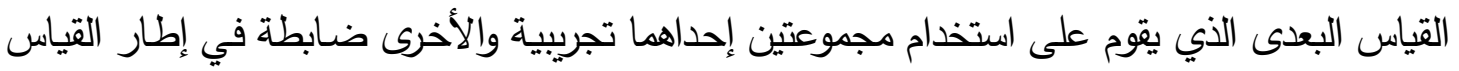

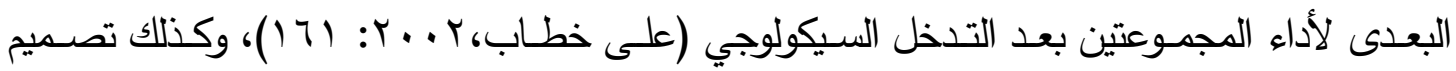

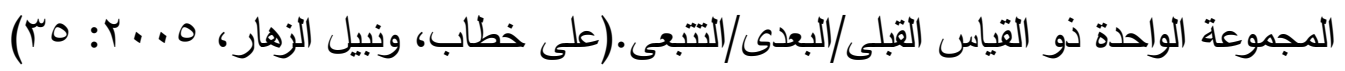

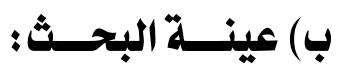
1- إعينـــة ضبـــالأدوات:

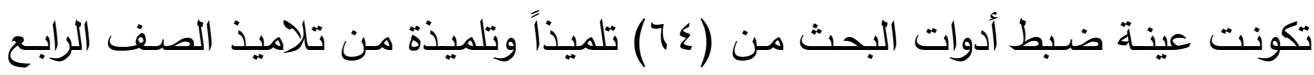

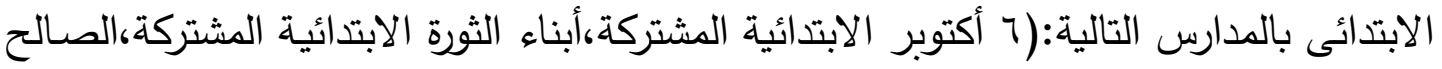

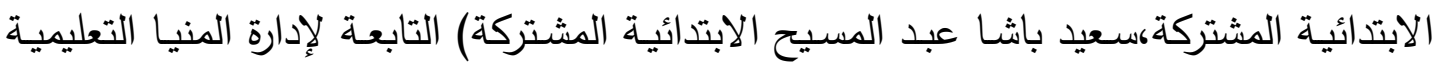




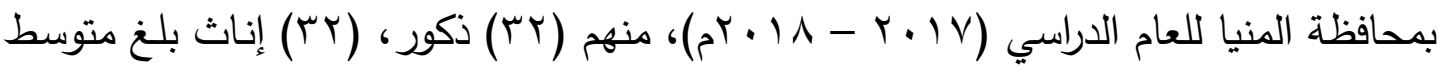

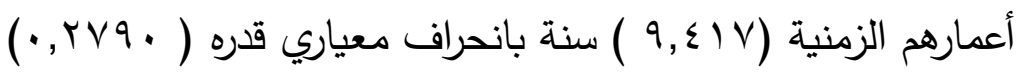

\section{r-عينــة البحـث الأساسيـة:}

تكونت عينة البحث الأساسية من ( • آ تلميذاً وتلميذة من تلاميذ الصف الرابع الابتدائى

منهم (Tr) ذكور ، (TV) إناث بواقع ن= • بكمجموعة تجريبية،ن= • ك كمجوعة ضسابطة، مدن لايهز صعوبات تعلم في مادة الرياضيات، ولقد الثتقت هذه العينة من بين أفراد العينة الأولية والتي بلغ عدد أفرادها (• • إ) تلميذاً وتلميذة من تلاميذ الصف الرابع الابتدائى بمدارس (اللمطى الابتدائية المشتركة، النيل الابتدائية المشتركة،المنتزة الابتدائية المشتركة، النظام الابتدائية المشتركة ،الانجيلية الابتدائية المشتركة) التابعة لإدارة المنيا التعليمية بمحافظة المنيا ومتوسط الأعمار الزمنية للمجموعة

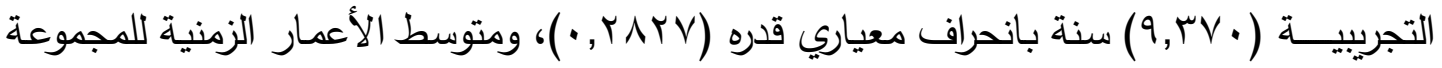

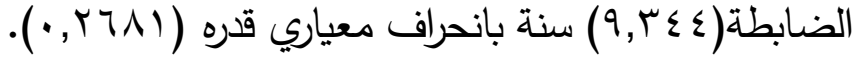

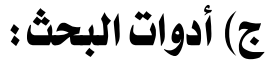

\section{أولاً: أدوات تشفيص النقاميذ ذوى صعوبات التعلم:}

قد استعانت الباحثة ببعض الأدوات لتشخيص عينـة البحث الأساسية ومنها (اختبار

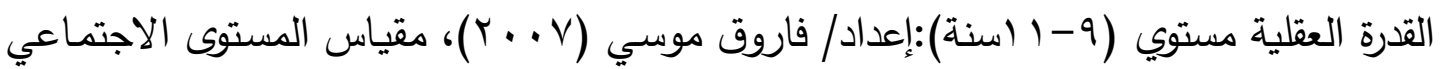
والاقتصـادي والثقافى (المطور) للأسرة المصرية: إعداد/ محمد خليل(ب ... ب)، اختبار الفرز العصبى السريع لفرز التلاميذ ذوى صعوبات التعلم: Quick Neurological Screening إقتباس وإعداد/ مصطفى كامل (Y..人est (QNST) بالإضافة إلى الأدوات التى قامت بإعدادها،والموضحة فيما يلى:

ا- الاختبار التشخيص لوحدتى (المضاعفات والعوامل وقابليـة القسـمة،القياس)

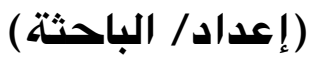

يهدف الاختبار التشخيصسى إلى التحديد الدقيق للصعوبات التى تواجه التلاميذ فى دراستهم لموضوعات وحدتى (المضـاعفات والعوامل وقابلية القسمة،القياس) بمـادة الرياضيات المقررة على تلاميذ الصف الرابع الابتدائى، ولتحديد ذلك قامت الباحثة بالخطوات التالية: 


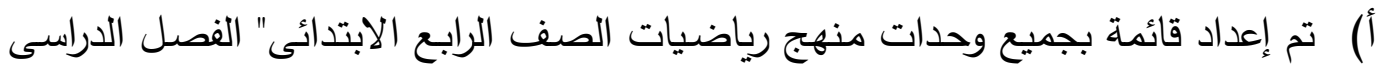

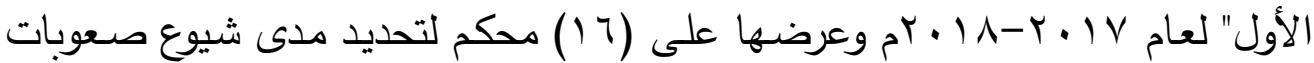
تعلم الرياضيات لكل موضوع من موضوعات وحدات المنهج، وتم حساب مربع كاى تم تحديد الموضوعات التى حصلت على نسبة مئوية للشيوع .. 1\% فتركزت الصعوبات فـى وحدتين ( المضــاعفات والعوامـل وقابليـة القسـمة، القيـاس)، ثم تم إعداد قائمــة بصعوبات تعلم كل موضوعات الوحدتين وعرضها على (7 (1) محكم وتم حساب نسبة الإتفاق بين المحكمين بإستخدام معادلة "كوبر cooper" وتم الإبقاء على الصعوبات التى حصلت على نسبة اتفاق بين المحكمين أعلى من ـ1\% ووفقاً للنسبة التى حددها

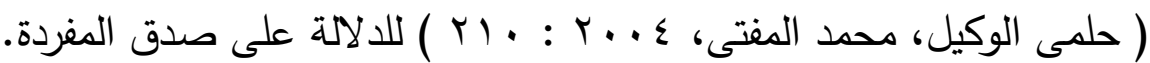
ب) تم إعداد جدول مواصفات الاختبار التشخيصى للوحدتين التشين ج) تم صياغة مفردات الاختبار بطريقة موضوعية شملت ( الاختيار من متعدد، الإكمال، الصواب والخطأ، الإيجاد، التحليل، الترتيب، الاستتناج)، كذلك تحديد تعليماته وتحديد

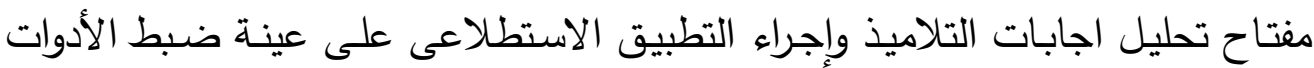
(ن= \& 7$)$ 1-صـــق الاختبـار التشخيصسى: تـم التحقـق مـن صـدق الاختبـار مـن خـلال صـدق المحكمين ،حيث تم عرض الاختبار على مجموعة من المحكمين وعددهم (• (1) محكم

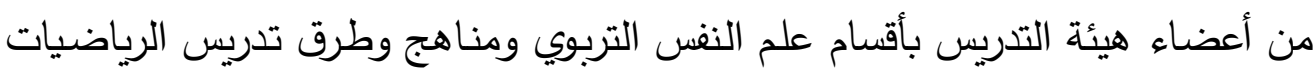

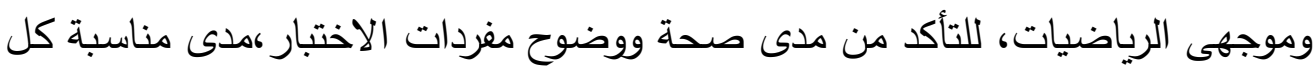
مفردة للصعوبة التى وضعت لقياسها، تم حذف المفردات التى حصلت على نسبة أقل الت من •^^\% والإبقاء على المفردات التى حصلت على نسبة أعلى من •^^\% وفقاً لدعادلة

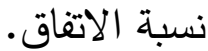

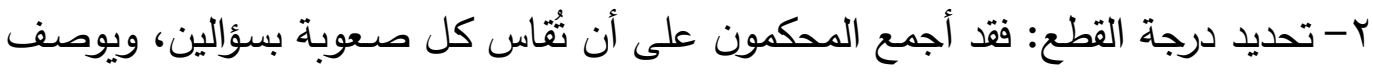

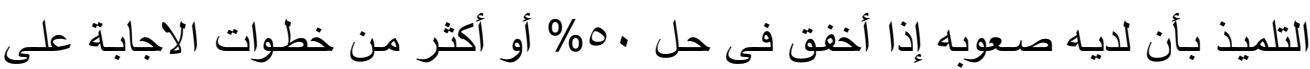
أسئلة الصعوبة.

ب- تحديد زمن تطبيق الاختبار : أمكن حساب الزمن اللازم للتطبيق باستخدام المعادلة

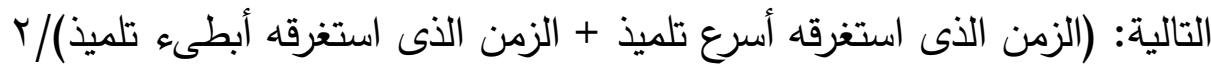

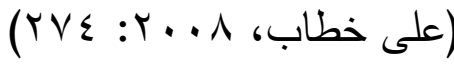




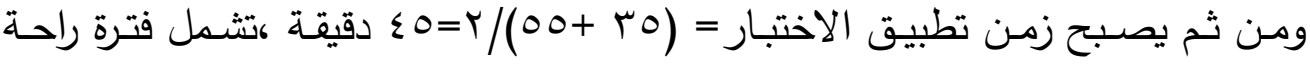
وقدرها خمس دقائق بين الاختبار الأول والثانى.

\section{r- مقياس العبء المعرفي:(إعداد/ الباحثة)}

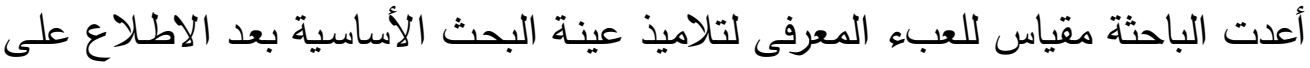
الأدبيات والدراسات السابقة والمقاييس التى تتاولت العبء المعرفى ومنها:

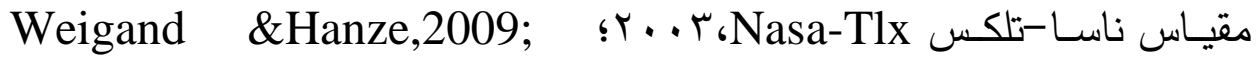
Antonenko\&Niederhauser,2010; $\quad$ Kalyuge,2010

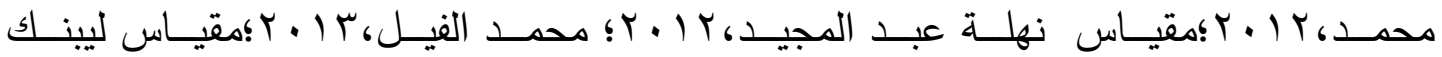

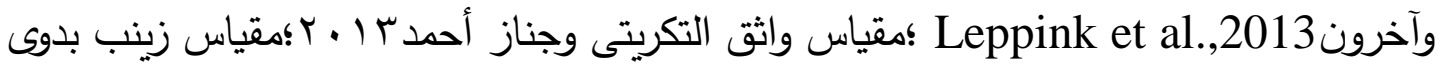

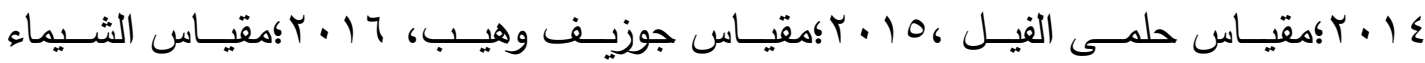

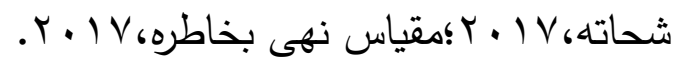

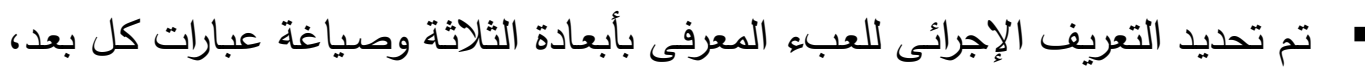
وأمام كل عبارة ثلاثة بدائل (تنطبق ،تتطبق احياناً، لاتتطبق) وتقدر الدرجات عليه كما لإسا

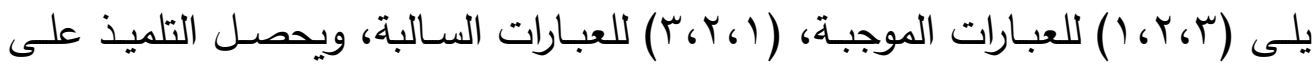

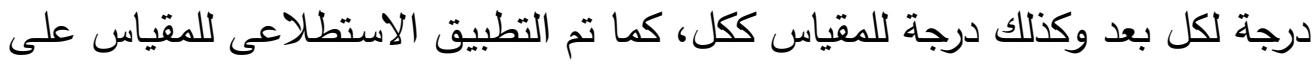

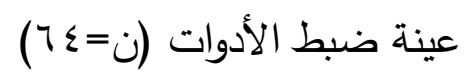

• أمكن حساب الزمن اللازم للتطبيق باستخدام المعادلة التالية:

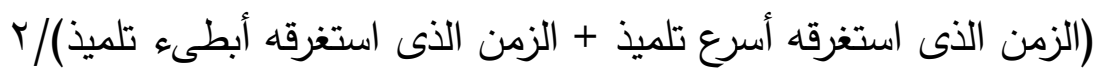

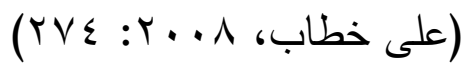

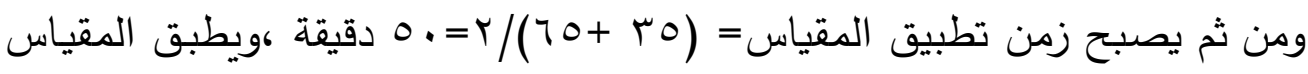

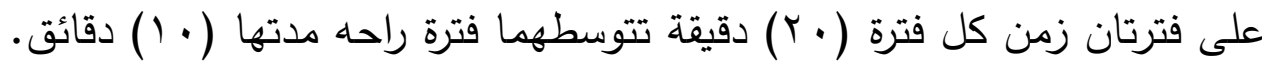
الخصائص السيكومترية لمقياس العبء المعرفى: أولاً:صدق المقياس

تم التحقق من صدق المقياس بطريقتين صدق المحكمين وصدق المحك الخارجى كما يلى:-

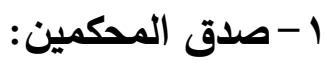
تم إعداد المقياس فى صورته الأولية وعرضه على (Y I ) محكم من أعضاء هيئة

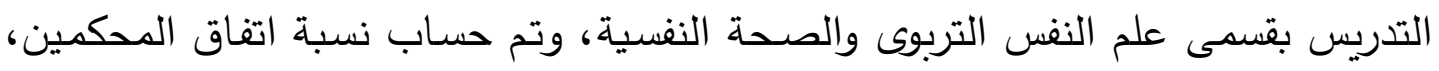


وتم إجراء بعض التعديلات التى أوصى بها السادة ليصبح المقياس فى صورته النهائية مكون من (جq) عبارة موزعة على النحو التالى:

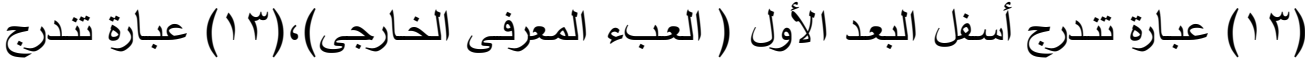

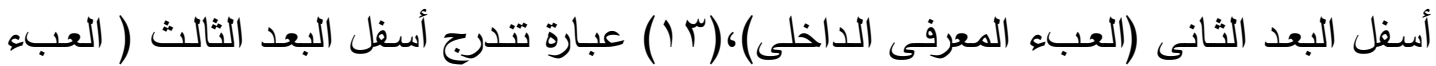

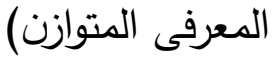

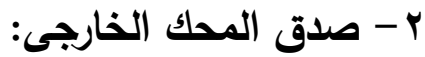
تم التحقق من صدق مقيساس العبء المعرفى بطريقة صدق الدحك وذلك بحسـاب معامل الارتباط بين درجات عينة ضبط الأدوات (ن=ء T) على مقياس العبء المعرفى (إعداد/ الباحثة) ودرجاتهم على مقياس الذكاء إعداد/ فاروق موسى (V · . r)، وتحصيل العام السابق

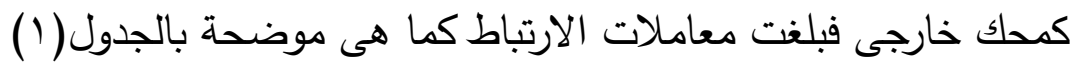

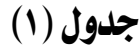

معاملات ارتباط أبعاد مقياس العبء المعرفى باختبار الذكاء وتحصيل العاه السابق كمحك خارجى

\begin{tabular}{|c|c|c|}
\hline \multicolumn{2}{|c|}{ قيم معاملات ارتباط بيرسون } & \\
\hline تحصيل العاه السابق & اختبار الذكاء & 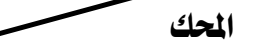 \\
\hline$* * *$, 1 $\vee$ - & $* * \cdot, r \cdot r-$ & العبء المعرفى الخارجى \\
\hline ***, YOr- & $* * *, \Gamma T-$ & العبء المعرفى اللاخلى \\
\hline$* * *, 79 \Lambda-$ & $* * *, 7 \wedge 9-$ & العباء المعرفى المتوازن \\
\hline$* * *, 917-$ & $* * *, 91 \xi-$ & العبء الكلى \\
\hline
\end{tabular}

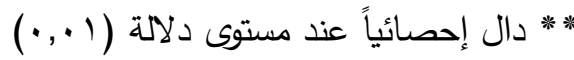

وتثير الإثارة السالبة إلى طبيعة العلاقة العكسية بين العبء المعرفى وكل من الذكاء

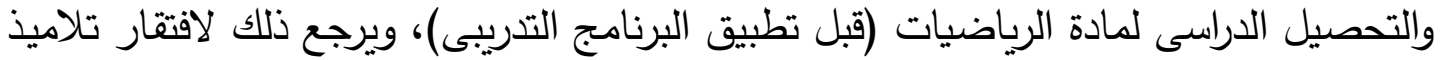

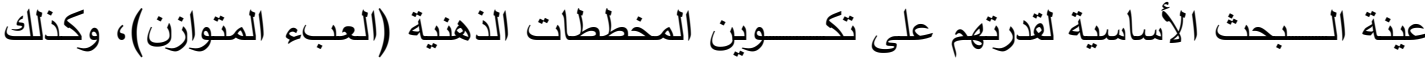

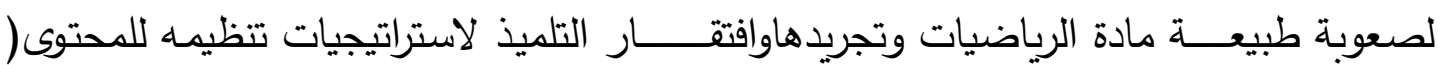

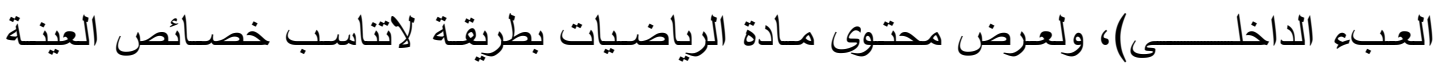
المعرفية والسلوكية، ومسن ثم العبء الكباء الكلى. ثانياً: ثبات المقياس

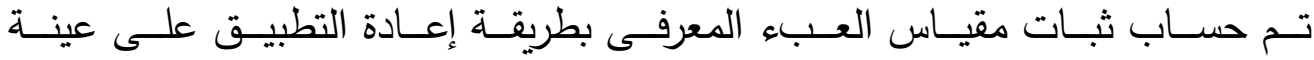

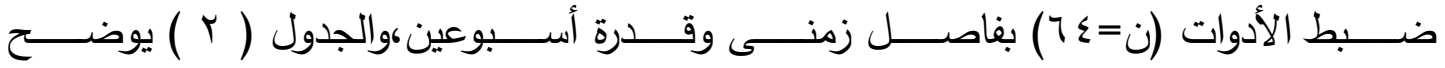
معاملات ثبات أبعاد المقياس. 


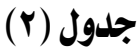

معاملات ثبات أبعاد مقياس العبء المعرفى بطريقة إعادة التطبيق(ن=\{؟)

\begin{tabular}{|c|c|c|}
\hline معاملات الثبات & أبعاد المقياس & هـ \\
\hline ***, arr & العبء المعرفى الخارجى & 1 \\
\hline$* * *, 900$ & العبء المعرفى اللداخلى & r \\
\hline$* *$, aVr & العبء المعرفى المتوازن & r \\
\hline$* * *, 901$ & العبء الكلى & $\xi$ \\
\hline
\end{tabular}

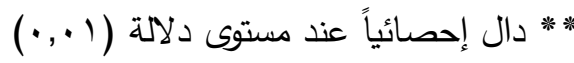

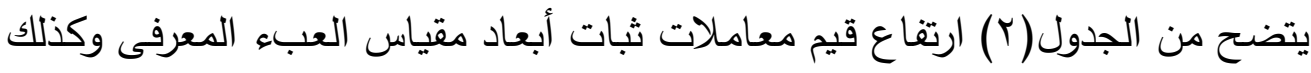

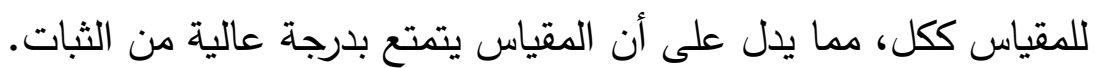

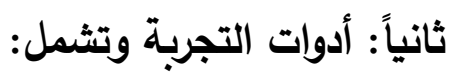
1- الاختبار التحصيلى لوحدتى المضاعفات والعوامل وقابلية القسمة،القياس :

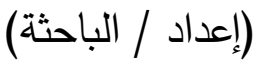

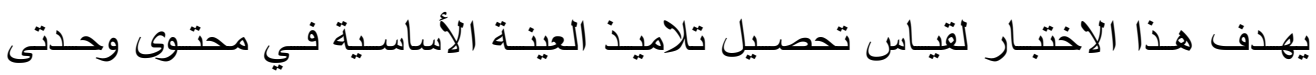
(المضـاعفات والعوامل وقابلية القسمة، القياس ) من مقرر رياضيات الفصل الدراسيى الأول

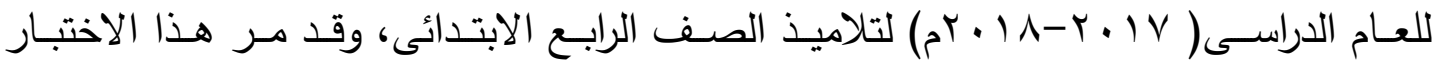
بمجموعة من الخطوات، نوضحها فيمايلى: أ) تحديد المجال السلوكي الذي يقيسه الاختبار : وتم ذلك من خلال تحديد الأهداف العامة

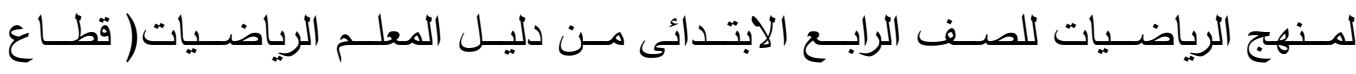

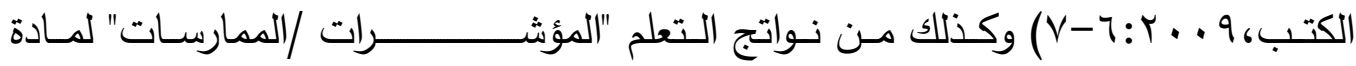

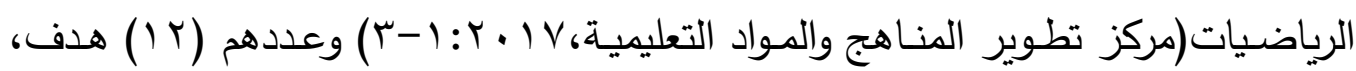

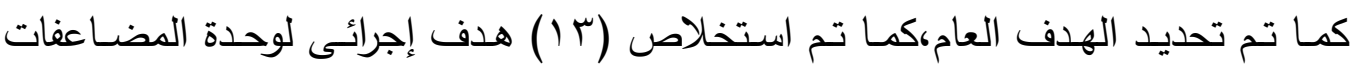

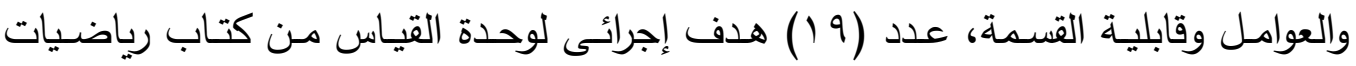

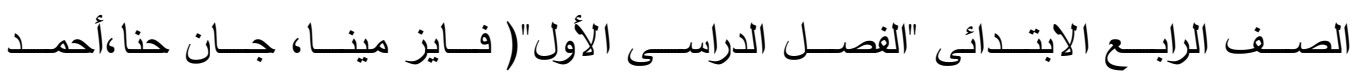

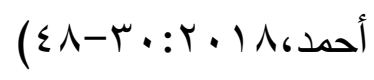

ب) تحليل محتوى وحدتى ( المضاعفات والعوامل وقابلية القسمة، القياس):

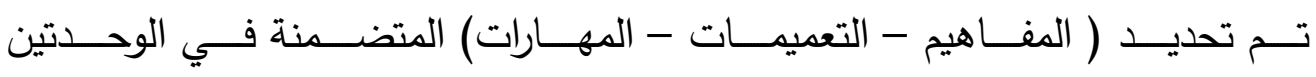

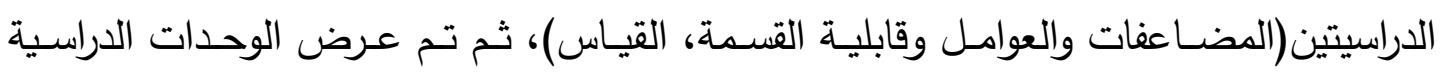

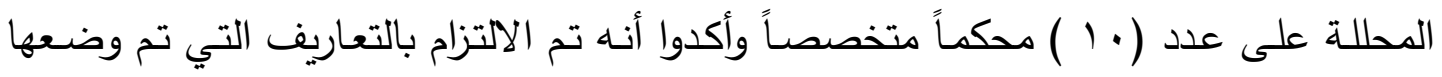


للففهوم والتعميم والمهارة الرياضية طوال فترة التحليل، كما أكدوا على دقة الصياغة اللغوية ،كما تم تحديد ثبات التحليل التحليل باستخدام معادلة "هولستي Holsti" C.R =2M /(N1 + N2) •

• حيث M عدد الفئات المتفق عليها في مرتي التحليل، N1+ N2 هي مجموع عدد

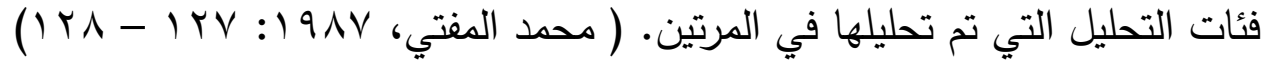
وتوصـلت نتـائج التحليـل إلى معامـل ثبـات (90, • \%) بـين مرتـى التحليـل لوحـدة (المضاعفات والعوامل وقابلية القسمة)، وإلى معامل ثبات (79 , •\%) بين مرتى التحليل لوحدة (القياس) مما يشير إلى أرتفاع ثبات التحليل للوحدتين لأنها تفوق نسبة (10, • \%) التى أشار إليها (فضل دليو، 10 • ب:0 1 ) لأرتفاع ثبات التحليل.

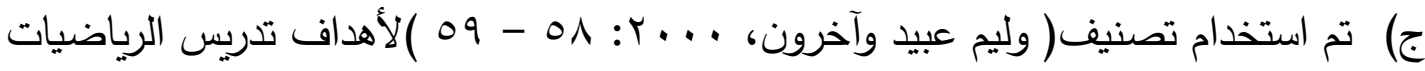

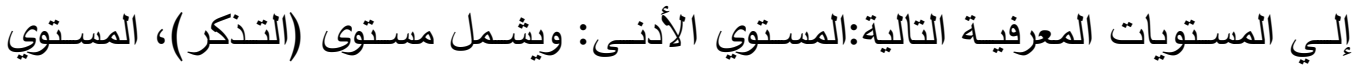
المتوسط: وشمل مستويى:(الفهم - التطبيق)، المستوي الأعلى: ويشمل مستوى (التحليل) وتم تعريفهم إجرائياً د) م إعداد جدول المواصفات للاختبار التحصيلي من خلال تحديد الأهمية النسبية لكل موضـوع مـن موضـوعات الوحـدة فـي ضـوء: (عـد الصـفـات، الفترة الزمنيـة "عـدد

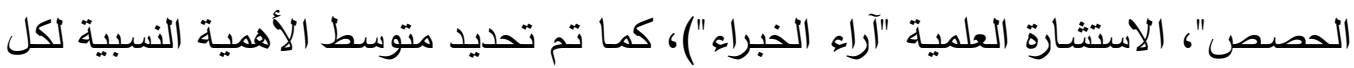

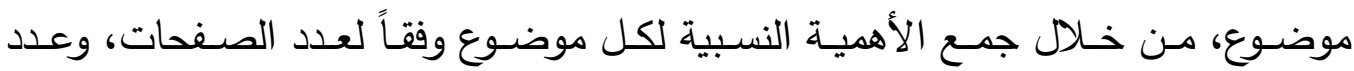
الحصص، ولآراء الخبراء، ثم قسمتها على عددها، كما تم حساب الوزن النسبي (الأهمية النسبية) لكل هـف مـن الأهـاف السـلوكية لموضـوعات الوحدتين الدراسيتين، وذلك بالاعتمـاد على محك آراء الخبراء ثثم تم إعداد جدول المواصـفات الخـاص بالاختبـار التحصيلي في ضوء ما توصلت إليه من نتائج تتعلق بالأهمية النسبية للأهداف التعليمية وموضوعات المحتوى، وذلك وفقاً للمعادلة التالية: الأهميـة النسـبية لكـل خليـة = (الأهميـة النسـبية للموضــوع × الأهميـة النسـبية

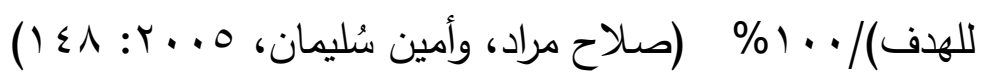




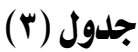

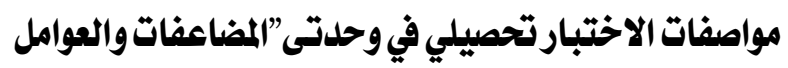

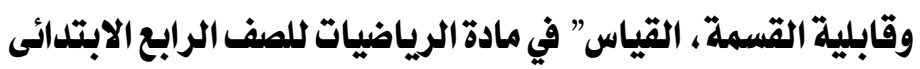

\begin{tabular}{|c|c|c|c|c|c|c|}
\hline \multicolumn{7}{|c|}{ أولاوحلدة : المضاعفات والعوامل وقابلية القسمة } \\
\hline \multirow{2}{*}{ الأهمية النسبية للمحتوى } & \multicolumn{4}{|c|}{ الأهـــــاف التعليميــة } & \multirow{2}{*}{ الموضـــــع } & \multirow{2}{*}{ A } \\
\hline & 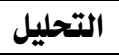 & التطبيق & الفهر & 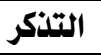 & & \\
\hline$\%$ ro & - & $\%$ & $\%$ & $\%$ & المضاعفات & 1 \\
\hline$\%$ r. & - & - & $\%$ r. & - & قابلية القسمة & $r$ \\
\hline$\%$ & $\%$ & - & $\%$ ro & - & العوامل والأعداد الأولية & r \\
\hline$\%$ & - & $\%$ & - & - & العوامل المشتركة ع.م.أ & $\xi$ \\
\hline$\%$ & - & $\%$ & $\%$ & - & المضاعفات المشتركة م.ر.أ & 0 \\
\hline$\%$ & $\%$ & $\%$ ro & $\% 00$ & $\%$ & \multicolumn{2}{|l|}{ الأهمية النسبية للأهداف } \\
\hline \multicolumn{7}{|c|}{ ثانيا وحلة : القياس } \\
\hline الأهمية النسبية للمحتوى & \multicolumn{4}{|c|}{ الأهـــــاف التعليميــة } & \multirow{2}{*}{ الموضــــع } & \multirow[b]{2}{*}{ ه } \\
\hline (الموضوعات) & 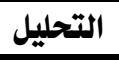 & التطبيق & الفهر & التذكر & & \\
\hline$\% \Gamma r, r T$ & - & $\%$ \% & $\% 11,11$ & - & 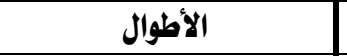 & 1 \\
\hline$\% 77,77$ & - & $\%, 00,00$ & $\% 11,11$ & - & 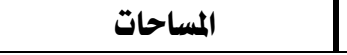 & r \\
\hline$\% 1 .$. & - & $\% \mathrm{rv}, \mathrm{vr}$ & $\% r r, r r$ & - & \multicolumn{2}{|l|}{ الأهمية النسبية للأهداف } \\
\hline
\end{tabular}

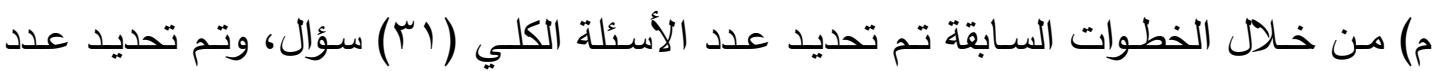

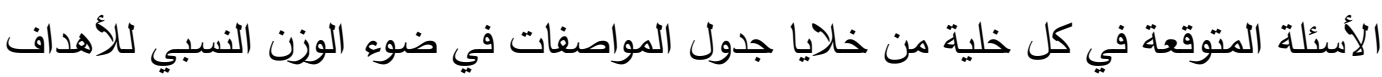
والموضوعات، وذلك باستخدام المعادلة التالية:

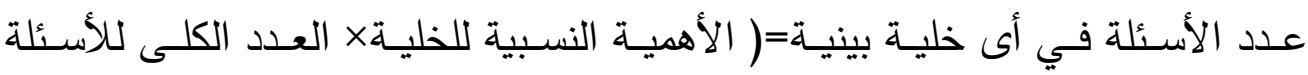

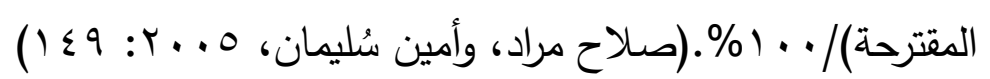

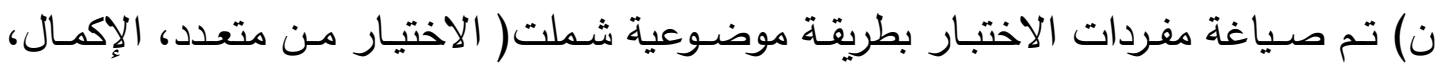

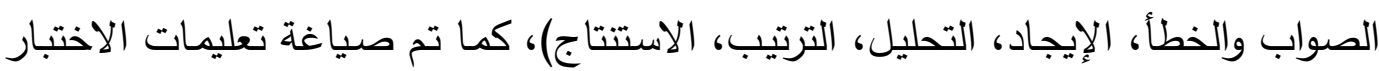

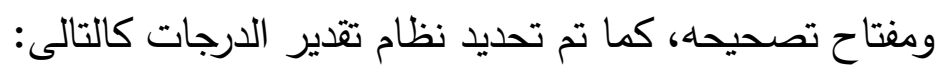

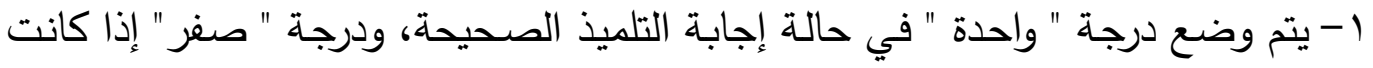
إجابته خاطئة، وذلك لكل سؤال من أسئلة الاختيار من متعدد أو الإكمال.

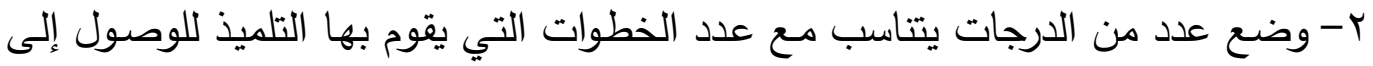
الحل الصحيح لكل سؤال من الأسئلة (التحليل- الاستنتاج- الإيجاد - التحليل). 


\section{هـ) التحقق من الخصائص السيكومترية للاختبار :}

للتحقق مـن صـلاحية الاختبار للاستخدام والتطبيق تم تجربته على مجموعـة ضسط

أدوات البحث (ن=ع 7) تلميذاً وتلميذة من تلاميذ الصف الرابع الابتدائى، وقد تم ذلك بهدف:

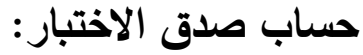

صدق المحتوى (المحكمين):

تم عرض الصورة الأولية للاختبار على ( • () محكّماً متخصصاً ،ثم تم تفريخ البيانات وحساب نسبة الإتفاق بين المحكمين بإستخدام معادلة "كوبر cooper"

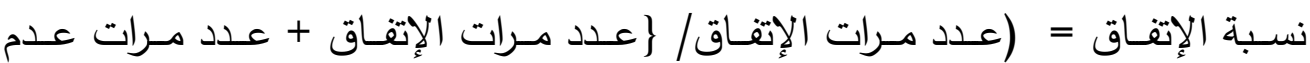

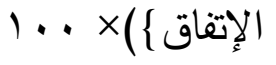

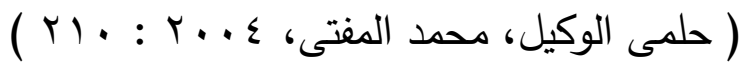

وكانت نسبة الاتفاق بين المحكمين لجميع مفردات المقياس ، . . (\% ويدل ذلك على

$$
\text { ارتفاع صدق المقياس. }
$$$$
\text { صدق المحك الخارجى: }
$$

تم التحقق من صدق الاختبار التحصيلى المستخدم فى البحث الحالى بطريقة صدق المحك وذلك بحساب معامل الارتباط بين درجات عينـة ضبط الأدوات (ن=ع 7) على الاختبار التحصيلى الحالى إعداد/ الباحثة ودرجاتهم على مقياس الذكاء إعداد/ فاروق موسى (ع ـ . ب) وكذلك التحصيل العام الدراسى السابق.

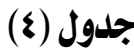

\begin{tabular}{|c|c|c|}
\hline \multicolumn{2}{|c|}{ قيم معاملات ارتباط بيرسون } & \\
\hline تحصيل العامر السابق & 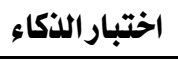 & \\
\hline$* * \bullet$, qrV & $* * \bullet, \wedge I 1$ & الاختبار الأول \\
\hline$* * \bullet, 9 r q$ & $* * \cdot, 1 \cdot 9$ & الاختبار الثانى \\
\hline$* * \bullet, 9 \wedge \mathrm{V}$ & $* * \bullet, \wedge \leqslant 9$ & الاختبار الكلى \\
\hline
\end{tabular}

معاملات ارتباط أبعاد الاختبار التحصيلى (باختبار الذكاء وتحصيل العام السابق) كمحك خارجى

$$
\begin{aligned}
& \text { * * دال إحصائياً عند مستوى دلالة (1 (., (•) } \\
& \text { r - حساب ثبات الاختبار: }
\end{aligned}
$$

تم التحقق من ثبات الاختبار بطريقة إعـادة التطبيق على عينـة ضـبط الأدوات

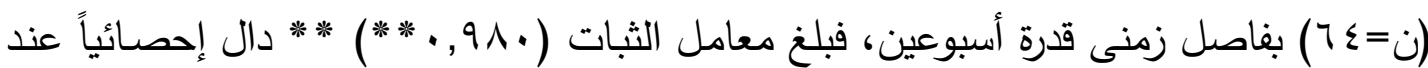

$$
\text { مستوى دلالة ( ( . , ))، وهى قيمة مرتفعة مما يدل على ثبات الاختبار . }
$$


أمكن حساب الزمن اللازم للتطبيق باستخدام المعادلة التالية

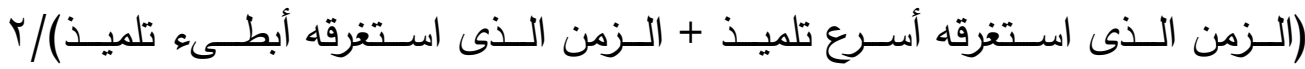

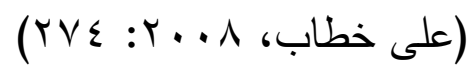

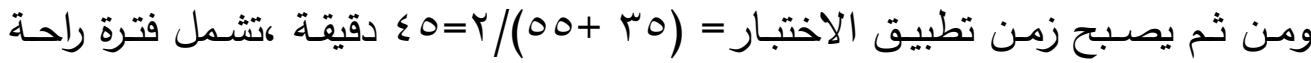
وقدرها خمس دقائق بين الاختبار الأول والثانى.

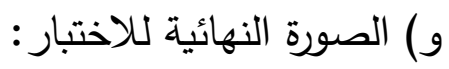
تم وضـع الاختبار التحصيلي في صورته النهائية مروراً بالخطوات السابقة، وأصبح الاختبار التحصيلي في صورته النهائية يتكوّن (9؟) مفردة، بواقع عدد(r) سؤال بمستوى التذكر ،(Y ( ) سؤال بمستوى الفهم، (Y) سؤال بمستوى التطبيق، (Y) سؤال بمستوى التحليل. البرنامج التدريبى المُعد في ضوء نظرية العبء المعرفى:(إعداد/ الباحثة)

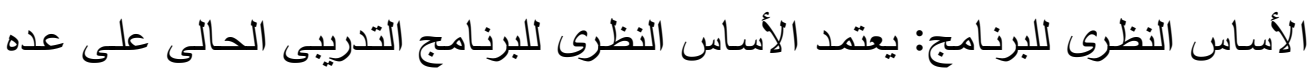
افتراضات مشتقة من نظرية العبء المعرفى متمثلة فى (المعالجة النشطة، ثنائية القنوات، تعدد

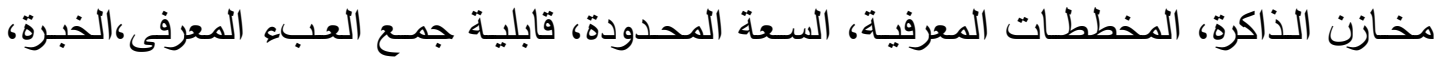
(Sweller,2004:20-23).(التعلم، الفهم، العشوائية، التخطيط)

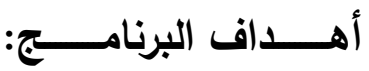
أولاً: الهدف العام للبرنامج: يهدف البرنامج التدريبى الحالى إلى خفض العبء المعرفى

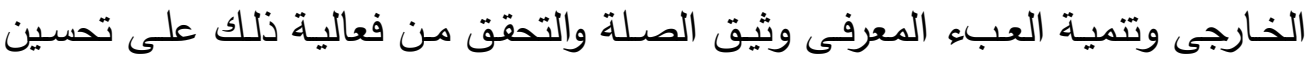

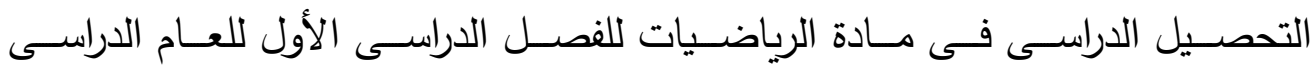

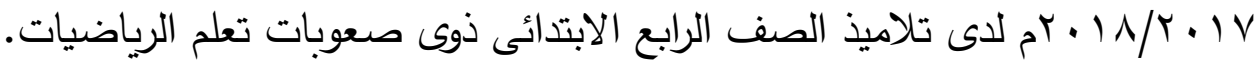

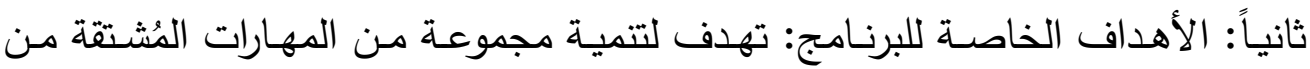
نظرية العبء المعرفى،وتعرف إجرائياً كما يلى: تلى تهاني

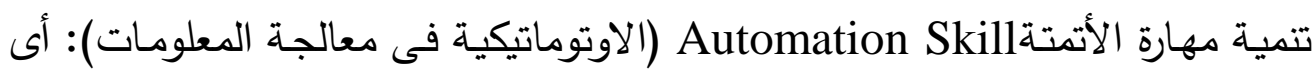
اكساب التلميذ القدرة على معالجة المعلومات بحد أدنى من الزمن اللازم للانتباه للمهمة وبأقل جها عقلى ممكن،وتثمل بعض المهارات الفرعية ،كما يلى:أ) مهارة انتاج الاستجابات:قدرة التلميذ على توليد استتاجات من معلومات معطاه. 
ب) مهارة سرعة الاستجابة:قدرة التلميذ على أداء المهمة بنجاح بأقل وقت وجهد ممكن. ج) مهارة المراقبة الذاتية:قدرة التلميذ على حساب أخطاءه في أدائه للمهام ومقارنته بين نتائج أدائه الفعلى والمتوقع.

د) مهارة التقويم الذاتى:قدرة التلميذ على الحكم على سلوكه المتبع فى عمليـة تـكر المعلومات وأداء المهام المسنده إليه .

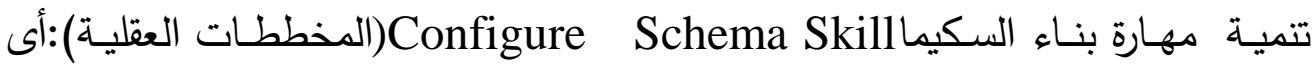
اكساب التلميذ القدرة على فهم المعلومات واختزالها فى قالب يسهل حفظ واستدعاء المعلومات من خلال ربط المعلومات الجديدة بالسابق تعلمها.، وتشمل بعض المهارات الفرعية ،كما يلى:مهارة الوعى بتقدير سعة الذاكرة: قدرة التلميذ على تقدير درجة سهولة وصعوبة المهام المسندة إليه وإدرالك مدى السهولة والصعوبة فى تذكرها.

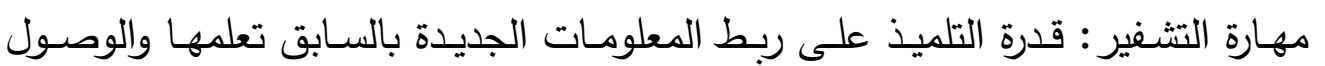
لتعميم ذو معنى. مهارة الاختزال: قدرة التلميذ على تلخيص كم كبير من المعلومات فى صيغة يسهل حفظها واستد عائها.

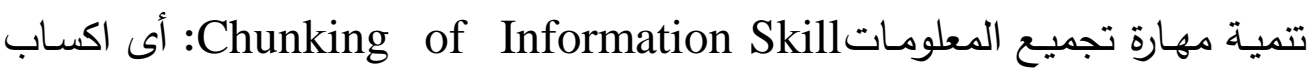
التلميذ القدرة على تصنيف المعلومات فى وحدات ذات معنى وفقاً لخاصية مشتركة، وتثمل بعض المهارات الفرعية كما يلى:مهارة التعرف:قدرة التلميذ على تفسير ووصف المعلومات المعروضة بدقه.

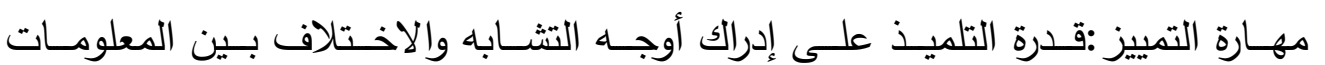

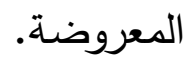
هـ مهـارة التنظيم الفئوى:قدرة التلميذ على تتظيم المعلومـات المعروضــة فـى فئـات وفـق

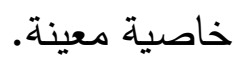

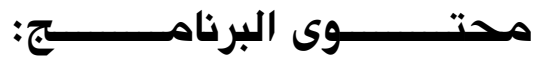

$$
\begin{aligned}
& \text { أولاً: المهام المستخدمة فى البرنامج }
\end{aligned}
$$

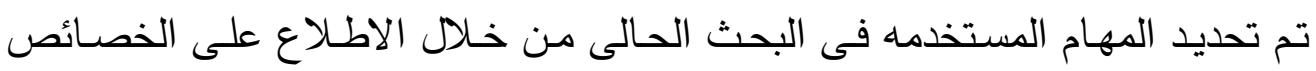

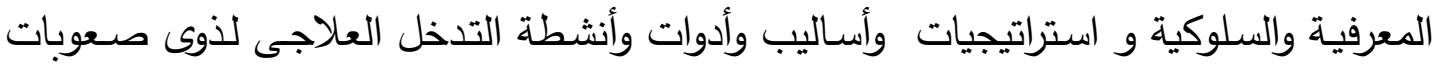

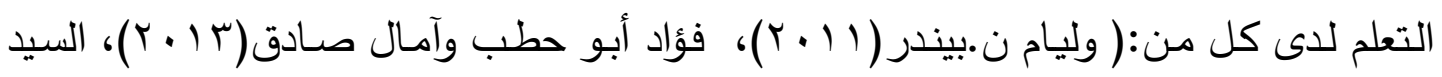




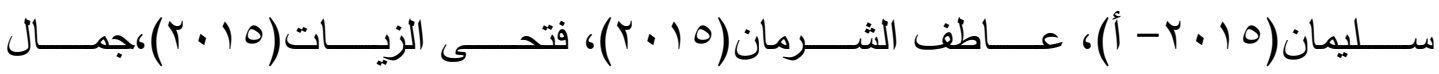

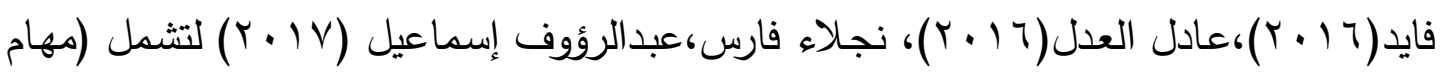
حسية، مهام بيئية، مهام فنية، مهام حركية، مهام تعليمية بواسطة الكمبيوتر ) ثانياً:الاستراتيجيات المستخدمة فى البرنامج.

قد استعانت الباحثة ببعض الاستراتيجيات المُشتقة من نظرية العبء المعرفى، وتعرف إجرائياً كما يلى:

1- استراتيجية الهدف الحر Free Gool Strategy:فنيه تهدف لتحفيز التلميذ لأنتاج أكبر قدر من الحلول للمهمة. r- استراتيجية المثال المحلول The Worked Example Strategy:فنيه تهدف الفرو،

لجذب انتباه التلميذ لتسلسل خطوات حل المهمة و تدريبه على استتناج قوانينها. r- استراتيجية إكمال المسألة Problem Complete: فنيه تهدف لزيادة ادراك التلميذ للروابط بين المعلومات المعطاه وتقديره لدرجة سهولة وصعوبة تذكره للمعلومات.

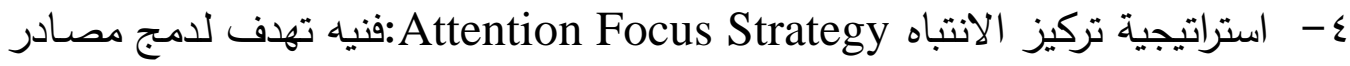

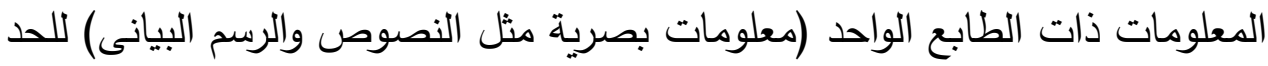
من أثز تشتت الانتباه. 0 - استراتيجية الثكلية Modality Strategy:فنيه تهدف لتوسيع حدود الذاكره العاملة من خلال تتظيم محتوى المهمة بحيث يتم عرض جزء منها سمعياً والآخر بصرياً. צ- استراتيجية الاختصار Concise Strategy:فنيه تهدف لعرض المعلومات بشكل ملخص دون إسهاب ليسهل حفظها واستدعائها. ثالثاً:الفنيات المستخدمة فى البرنامج . تم تحديد الفنيات المستخدمة فى البرنامج الحالى فى ضوء مااطلعت عليه الباحثة من

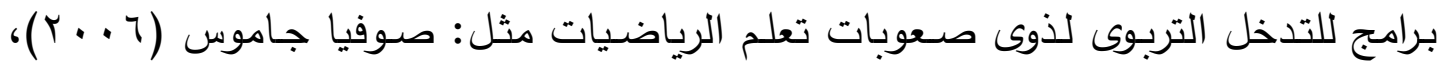

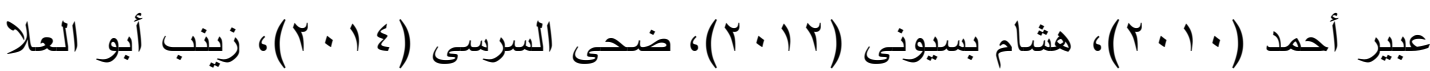

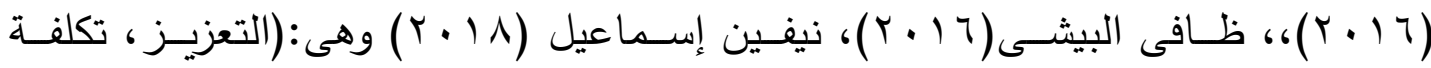

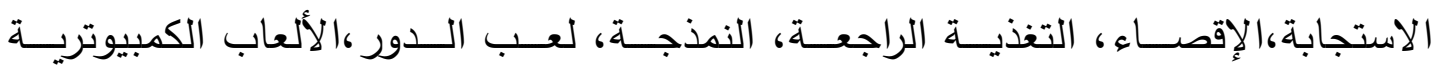


والتعليمية،الثرح، التكرار، المناقشة، الواجبات المنزلية، إدارة الدافعية،تنظيم الذات، حفظ

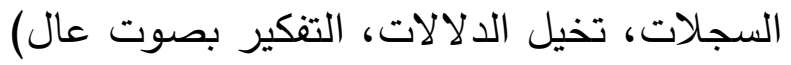

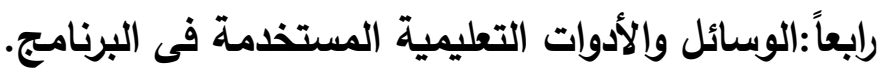

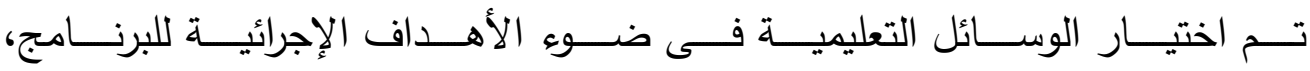

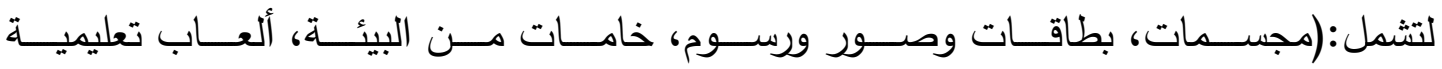
وكمبيوترية، ألعاب بنائية، ألعاب فك وتركيب) تقويم البرنامج التدريبى اعتمدت الباحثة علي أربعة أنواع من التقويم (القبلى، البنائى،البعدى، التتبعى) إجراءات ضبط البرنامج

بعد أن تم تصميم البرنامج فى صورته الأولية، تم عرضهه على مجموعة من السادة المحكمين المتخصصين وعددهم (r I ) محكم وذلك لإبداء آرائهم بشأن مدى ملائمسة البنود التالية (هدف الجلسة-مهارات الجلسة- الاستراتيجيات والفنيات المستخدمة في الجلسة -أدوات الجلسة- محتوى الجلسة والإجراءات -زمن تطبيق الجلسة) لعينة البحث، مدى ملائمة البرنامج لعينة البحث ،مدى وضوح المهام وسلامة اللغة والصياغة . قامت الباحثة بحساب نسبة الإتفاق بين المحكمين بإستخدام معادلة " كوبر " : نسبة الإتفاق= (عدد مرات الإتفاق / (عدد مرات عدم الإتفاق+ عدد مرات الإتفاق \{) × ...

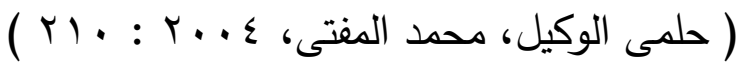
تراوحت نسبة الاتفاق فى بنود التحكيم بين (^v,0-. . ( )\%، ويدل ذلك على ارتفاع

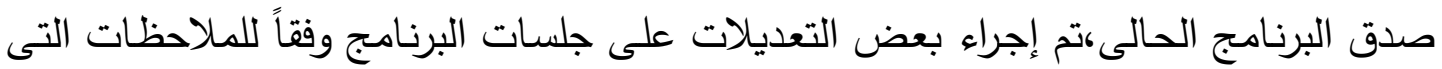

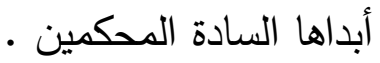
تم تجريب بعض جلسـات البرنـامج على عينـة ضبط أدوات البحث (ن= ع ؟) تلميذ

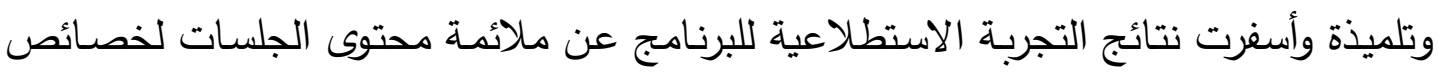
تلاميذ عينـة البحث وأهداف البرنامج، كما تم تحديد الزمن التجريبى للجلسات ليتراوح مابين (10:70 1 (10) دقيقة، ويختلف حسب طبيعة المهام فى كل جلسة ،وبعد إجراء ضبط البرنامج، أمكن تحديد جلسات البرنامج فى شكلها النهائى لتتكون من (9 ب) جلسة. 


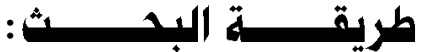

لقد سارت إجراءات البحث على النحو التالى :

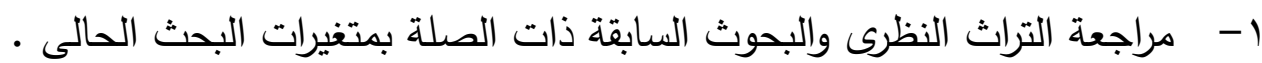

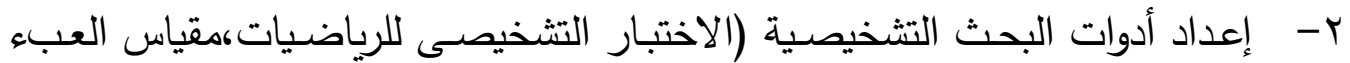

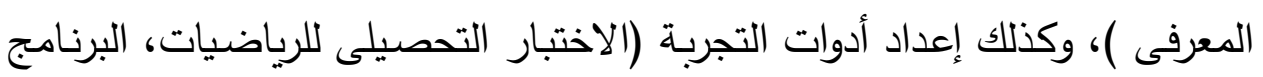

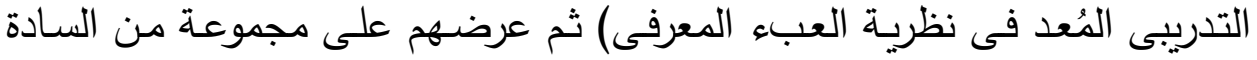
المحكمين للوصول للصورة النهائية لأدوات البحث.

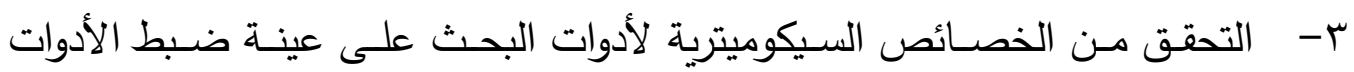
( $(\tau \leqslant=)$ ـ - الحصول على العينة الأساسية فى ضوء محكات تثخيص ذوى صعوبات التعلم ونتائج تحصيل العام الدراسى السابق لمادة الرياضيات.

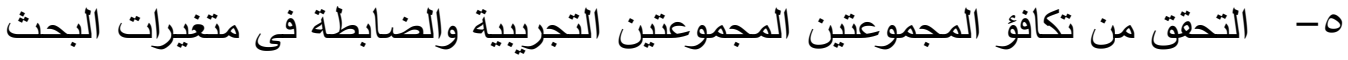

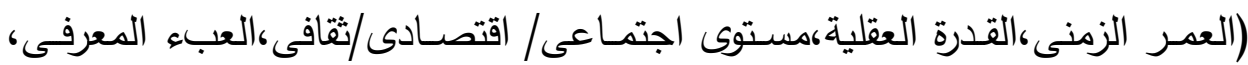
التحصيل الدراسى للرياضيات)

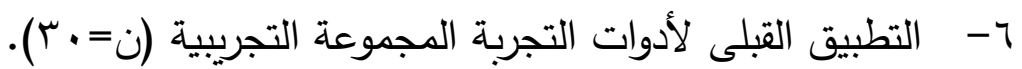

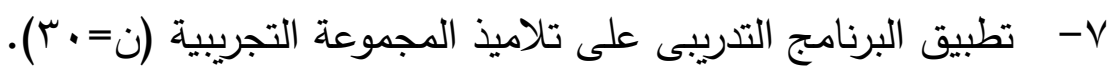

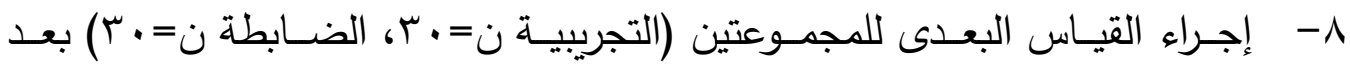
الإنتهاء من تطبيق جلسات البرنامج على المجموعة التجريبية. 9- إجراء القياس التتبعى لأدوات التجربة بفاصل زمنى قدرة شهر ونصف من القياس البعدى. • 1 تصحيح أدوات البحث طبقاً لما ورد فى التعليمات الخاصة لكل أداه.

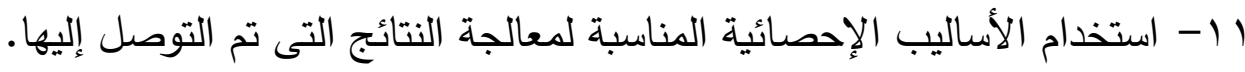

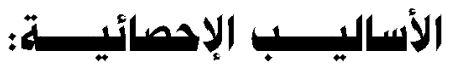

$$
\begin{aligned}
& \text { 1- المتوسطات والانحرافات المعيارية } \\
& \text { r- معاملات الارتباط }
\end{aligned}
$$

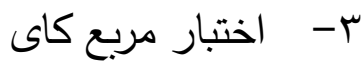

$$
\begin{aligned}
& \text { ع- معادلة هولستي } \\
& \text { 0- معادلة كوبر }
\end{aligned}
$$




$$
\begin{aligned}
& \text { 7- معادلة مربع ايتا لحساب حجم التأثير } \\
& \text { V- اختبار "ت" لعينتين مستقلتين } \\
& \text { 9- اختبار أقل فرق معنوى ( L .S.D }
\end{aligned}
$$

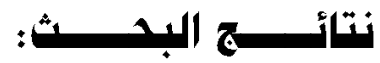

\section{نتائج الفرض الأول وتفسيره ومناقشته :}

ينص الفرض الأول على أنه. " توجد فروق دالة إحصائياً بين متوسطات درجات المجموعة

التجريبية في القياس القبلي والبعدي والتتبعي على الاختبار التحصيلي للرياضيات" وللتحقق من صحة هذا الفرض تم استخدام " تحليل التباين للقياسات المتكررة " في معالجة البيانات لحساب دلالة الفروق بين متوسطات القياسـات الثلاثة ( القبلي، البعدي، التتبعي ) للاختبارين الفرعيين (الاختبار الأول: الخاص بوحدة المضـاعفات والعوامل وقابلية القسمة، الاختبار الثانى: الخاص بوحدة القياس) وكذلك الاختبار التحصيلي الكلى للرياضيات، كما هو موضح بالجداول التالية:

\begin{tabular}{|c|c|c|}
\hline الانحراف المعيارى & المتوسط & القياس \\
\hline 1,87 & $9, V V$ & قبلى \\
\hline$r, \wedge q$ & $r r, r v$ & بعلى \\
\hline$\uparrow, \Lambda \uparrow$ & $r r, r$. & تتبعي \\
\hline
\end{tabular}

\section{جلدول(0)}

المتوسطات والانحرافات المعيارية للقياسات المتكررة للاختبار الفرعي الأول

الخاص بـ"وحلة المضاعفات والعوامل وقابلية القسمة" للمجموعة التجريبية (ن=•r)

\begin{tabular}{|c|c|c|c|c|c|}
\hline حربع التأثير & قيمة & متوسط التربعات & د.ح. & مجموع المربعات & التباين مصلر \\
\hline \multirow{4}{*}{ كبير } & \multirow{3}{*}{$* * \eta 9 \cdot, r \eta$} & \&,TIr & rq & $|r o, \bullet \&|$ & بين الأفراد \\
\hline & & $190 \cdot, \mathrm{V} 11$ & $r$ & $r q \cdot 1, \varepsilon r r$ & بيز الفترات \\
\hline & & Y,AYY & $\Delta \Lambda$ & $17 r, 911$ & الخطأ \\
\hline & & & 19 & $\xi 19 \cdot$, rV々 & الكلى \\
\hline
\end{tabular}

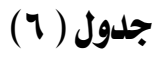

نتائج تحليل التباين للقياسات المتكررة للفروق بين متوسطات الاختبار الفرعي الأول

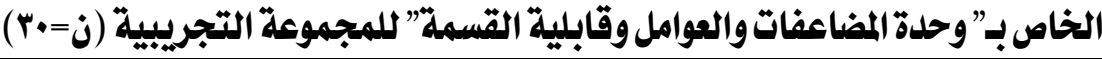




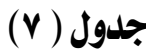

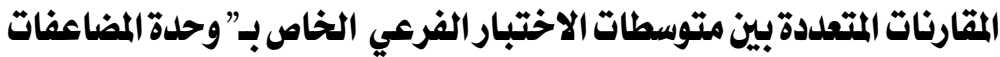

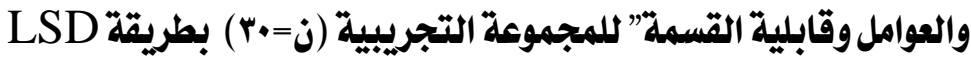

\begin{tabular}{|c|c|c|}
\hline فروق المتوسطات & \multicolumn{2}{|c|}{ 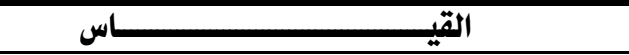 } \\
\hline $\begin{array}{l}* \mid \xi, \cdots- \\
* \mid r, q-\end{array}$ & تبعلى(V) & 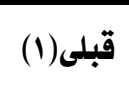 \\
\hline$\cdot, \cdot v$ & تتبعى(ץ) & بعلدى) (r) \\
\hline
\end{tabular}

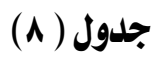

المتوسطات والانحرافات الميارية للقياسات المتكررة بـ متوسطات الاختبار الفرعي

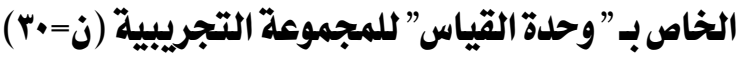

\begin{tabular}{|c|c|c|}
\hline الانحراف المعيارى & المتوسط & القياس \\
\hline $1,7 V$ & $r, 7 r$ & قبلى \\
\hline$r, r$ & 11,98 & بعدى \\
\hline$r, \cdot \cdot$ & 11,94 & تتبعى \\
\hline
\end{tabular}

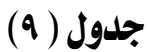

نتائج تحليل التباين للقياسات المتكررة للفروق بين متوسطات الاختبار الفرعي الخاص بـ "وحدة القياس” (باس

$$
\text { للمجموعة التجريبية (ن=•r) }
$$

\begin{tabular}{|c|c|c|c|c|c|}
\hline حربع التأثير & قيمة & متوسط المربعات & د.ح. & مجموع المربعات & التباين مصلر \\
\hline \multirow{4}{*}{ كبير } & \multirow{3}{*}{$* * 791$, roY } & I, Vฯ. & rq & $01, \cdot 0 r$ & بين الأفراد \\
\hline & & $190 \cdot, \mathrm{V} 11$ & r & IrAT, rOY & بين الفترات \\
\hline & & $r, \Lambda \cdot \varepsilon$ & $\Delta \Lambda$ & 17r, 7ะs & الخطأ \\
\hline & & & 19 & 109Y, ०0r & الكلى \\
\hline
\end{tabular}

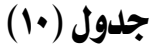

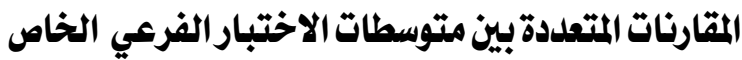

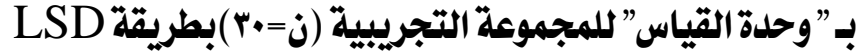

\begin{tabular}{|c|c|c|}
\hline فروق المتوسطات & لمستـــاس & 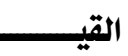 \\
\hline $\begin{array}{l}* \Lambda, \Gamma T- \\
* \Lambda, \%+-\end{array}$ & تتبعى(T) بعل) & قبلى(1) \\
\hline •, & تتبع(ץ) & 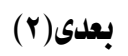 \\
\hline
\end{tabular}




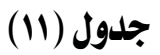

المتوسطات والانحر افات المعيارية للقياسات المتكررة للدرجة الكلية

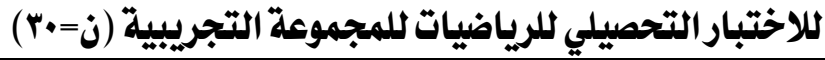

\begin{tabular}{|c|c|c|}
\hline الانحراف المعيارى & المتوسط & القياس \\
\hline$r, \cdot 1$ & |r, & قبلى \\
\hline$r, 79$ & $r \eta, \cdot v$ & بعدى \\
\hline$r, \wedge \uparrow$ & ro, & تتبعى \\
\hline
\end{tabular}

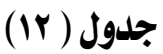

نتائج تحليل التباين للقياسات المتكررة للفروق بين متوسطات الدرجة الكلية

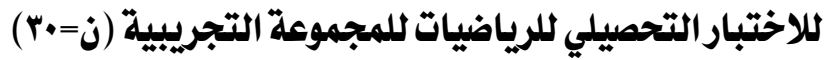

\begin{tabular}{|c|c|c|c|c|c|}
\hline حربع التأثير & قيمة & متوسط المربعات & د.ح. & مجموع المربعات & التباين مصدر \\
\hline \multirow{4}{*}{ كبير 97} & \multirow{3}{*}{$* * 919,900$} & $0,9 \Lambda$. & rq & $\mid V r,\{1 \mid$ & بين الأفراد \\
\hline & & $0 . \sum 1, \sum r r$ & $r$ & $1 \cdots \wedge r, \wedge \neg r$ & بيز الفترات \\
\hline & & $v, r \cdot v$ & $\Delta \Lambda$ & Err, & الخطأ \\
\hline & & & 19 & $1 \cdot 7 \Lambda \cdot, \cdot V \Lambda$ & الكلى \\
\hline
\end{tabular}

**** دال عند مستوى I +.

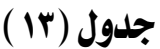

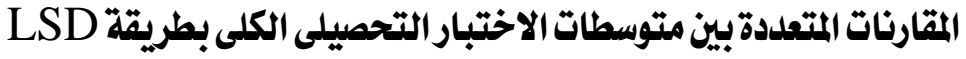

\begin{tabular}{|c|c|c|}
\hline فروق المتوسطات & لماس & \\
\hline $\begin{array}{l}* Y Y, T Y- \\
* Y Y, Y Y-\end{array}$ & تعلبعى(Y) ت ب (r) & قبلى(1) \\
\hline$\bullet,\{r$ & تتبعى(r) & بعدى(Y) \\
\hline
\end{tabular}

* دال عند مستوى 0 .,.

اتضـح من تحليل نتائج الفرض الأول إنـا قد تحقق جزئياً، حيث يتضـح من الجداول

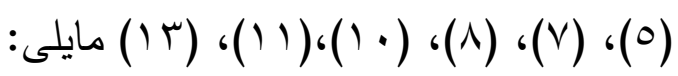

وجود فروق دالة إحصـائياً بين متوسطات درجات القياس القبلى والقياس البعدى عند

مستوي دلالـة (0. . • ) لصـالح القياس البعدى لكل من (الاختبار الفرعى الخـاص بـ"

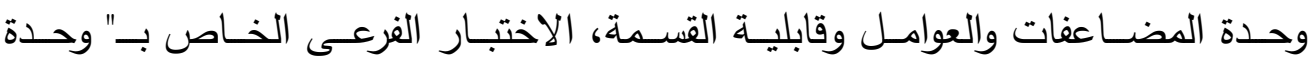

القياس،الاختبـار التحصـيلى الكلى للرياضـيات)، وهـذا يعنـي أن تلاميـذ المجموعـة

التجريبية الذين تم تدريهم على جلسـات البرنـامج التدريبى قد تحسن لديهم متوسط 
درجات(الاختبـار الفرعسى الخـاص بـ" وحـدة المضــاعفات والعوامـل وقابليـة القسـة، الاختبار الفرعى الخاص بـ" وحدة القياس،الاختبار التحصيلى الكلى للرياضيات)، مقارناً

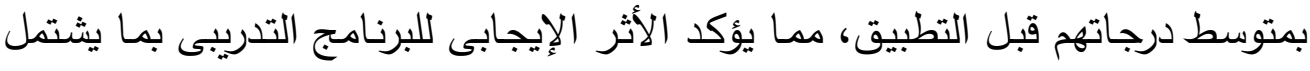

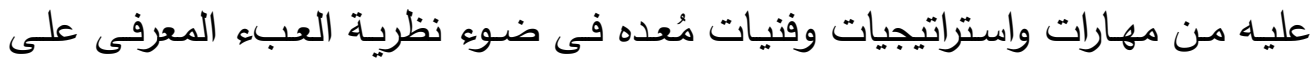
زيادة وتحسن تحصيل تلاميذ المجموعة التجريبية على (الاختبار الفرعى الخاص بـ" وحدة المضاعفات والعوامل وقابلية القسمة، الاختبار الفرعى الخاص بـ" وحدة القياس، الاختبار التحصيلى الكلى للرياضيات).

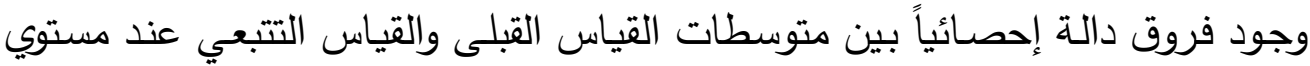

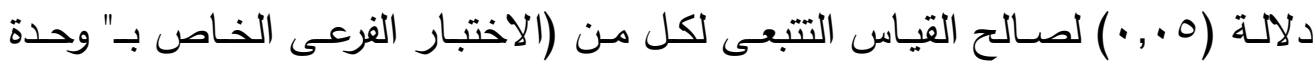

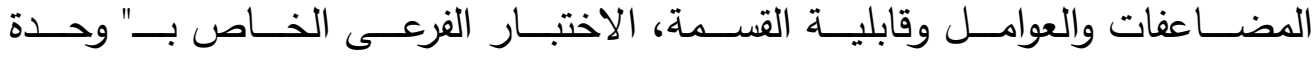

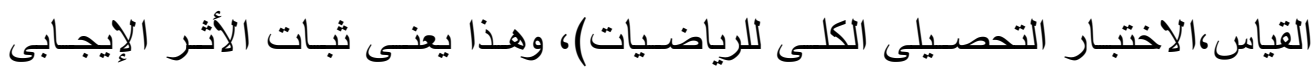
اللبرنامج لزيادة وتحسن تحصيل تلاميذ المجموعة التجريبية على لكل من (الاختبار

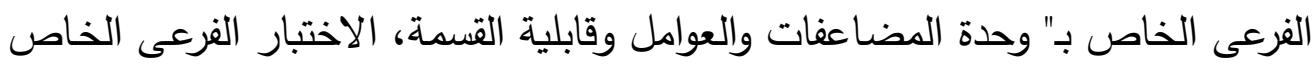
ب" وحدة القياس،الاختبار التحصيلى الكلى للرياضيات).

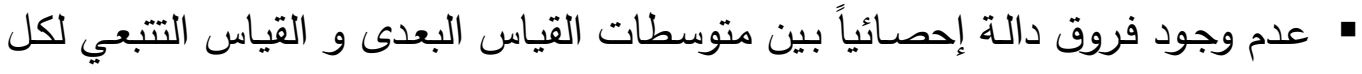
من (الاختبار الفرعى الخاص بـ" وحدة المضاعفات والعوامل وقابلية القسمة، الاختبار

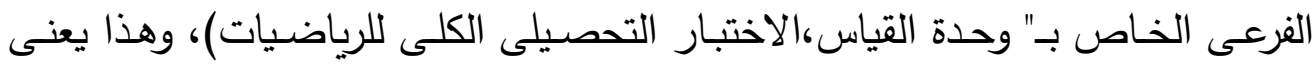

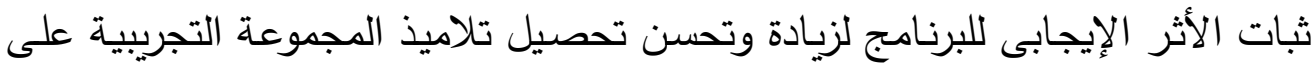

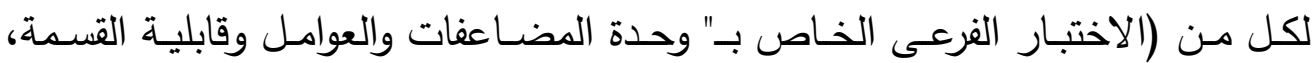
الاختبار الفرعى الخاص بـ" وحدة القياس،الاختبار التحصيلى الكلى للرياضيات).

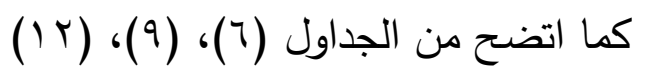

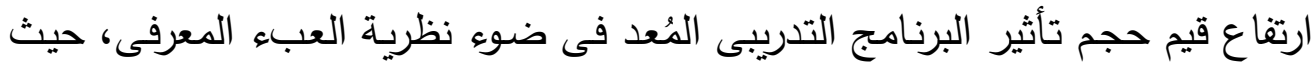

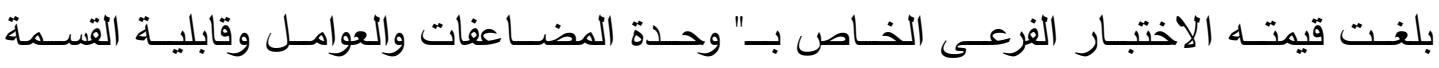

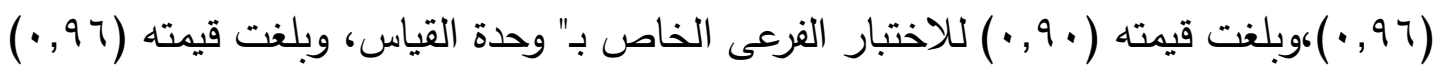

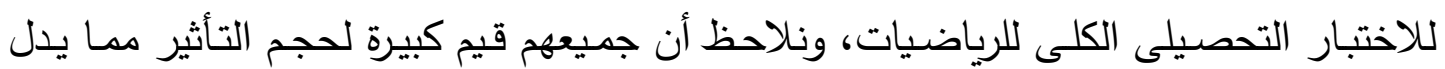
على فعالية البرنامج التدريبى فى زيادة وتحسن التحصيل الدراسى الكلى للرياضيات ونيات بما يشمله

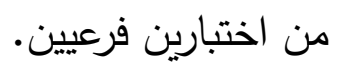


وتعزى الباحثة فعالية البرنامج التدريبى فى زيادة وتحسن التحصيل الدراسى للرياضيات

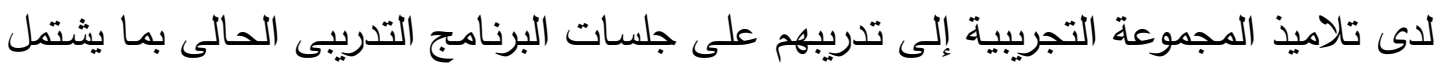

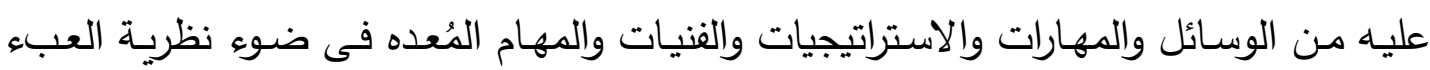

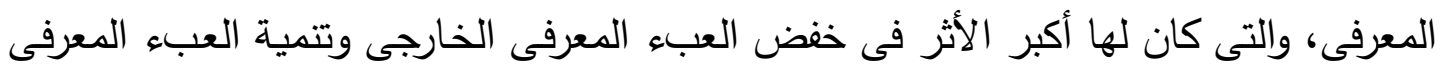

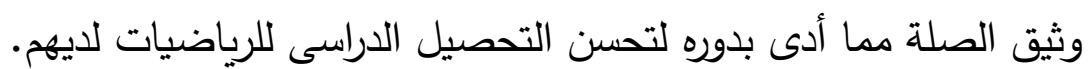

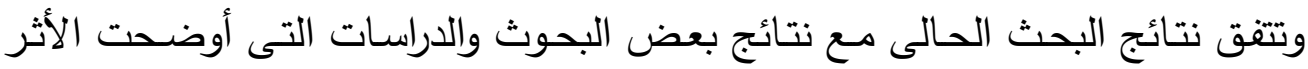
الإيجابى لتنمية العبء المعرفى وثيق الصلة وخفض العبء المعرفى الخارجى على تحسن

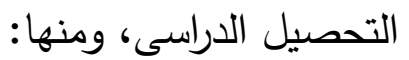

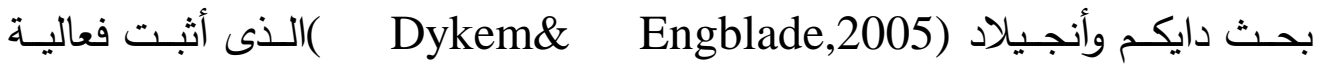

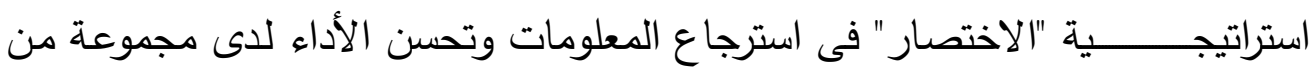

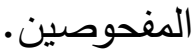
هراسة عادل البنا(^ . . r) التى أسفرت نتائجها عن فعالية استراتيجية " الهدف الحر"

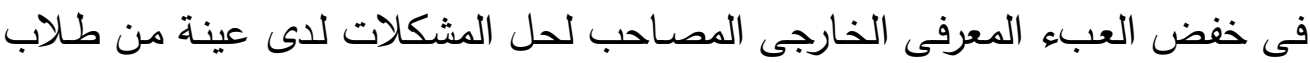

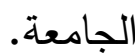

هراسـة وجند وهانز (Weigand \&Hanze,2009) التى أثبتت فاعلية استراتيجية

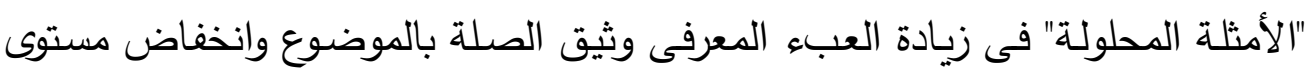
العبء المعرفى الدخيل وتحسن التحصيل الدراسى فى الفيزياء لدى عينة من طلاب الدياب المدرسة العليا لدراسة الفيزياء بألمانيا.

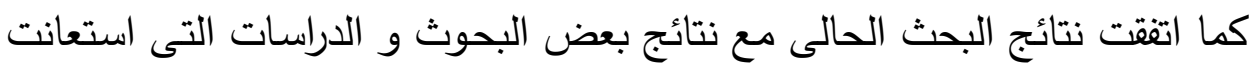

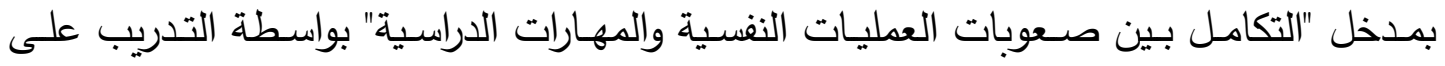

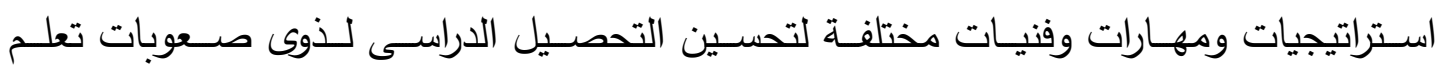

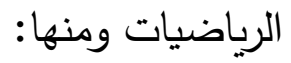

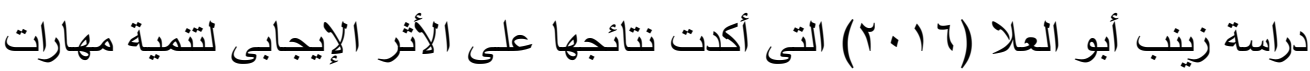

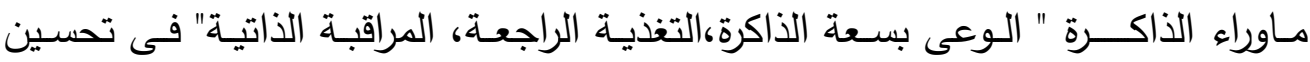
عادات الاستذكار وفاعلية الذات لدى تلاميذ العينة التجريبية.

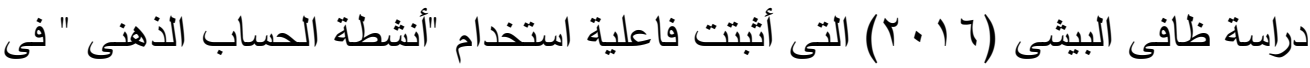
خفض صعوبات تعلم الرياضيات لدى عينة من تلاميذ المرحلة الابتدائية المتفوقين ذوى

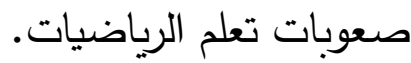




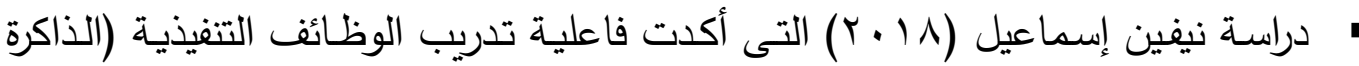
العاملة، حل المشكلات، التخطيط) في علاج بعض صعوبات تعلم الرياضيات للى إلى لدايل

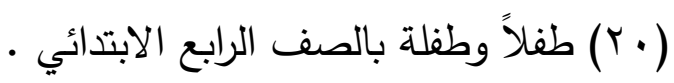

\section{نتائج الفرض الثانى وتفسيره ومناقشته :}

ينص الفرض الثانى على أنـه " توجد فروق دالـة إحصـائياً بين متوسطات درجات التهات

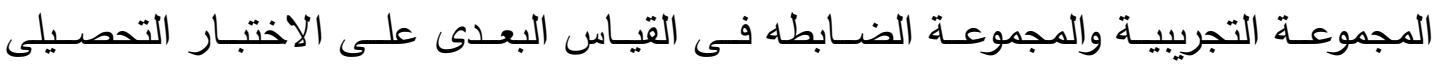
للرياضيات لصالح المجموعة التجريبية". وللتحقق من صحة هذا الفرض تم حساب كل من المتوسطات الحسابية والانحرافات

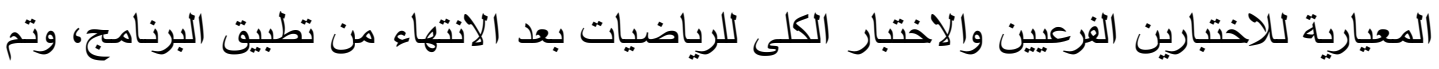
تطبيق اختبار" ت" لدلالة الفروق بين المتوسطات، كما هو مبين بجدول (ع (). جلدول (1)

دلالة الفروق بين متوسطات أداء المجموعة التجريبية و متوسطات أداء المجموعة الضابطة بعد المعالجة في

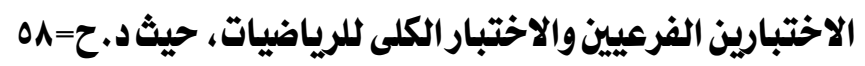

\begin{tabular}{|c|c|c|c|c|c|c|c|}
\hline \multirow{2}{*}{ التأثير( ) } & \multirow{2}{*}{ "قيمة" } & \multicolumn{2}{|c|}{ |المجموعة الضابطة } & \multicolumn{2}{|c|}{ المجموعة التجريبية } & \multirow[b]{2}{*}{ البعد الفرعى } & \multirow[b]{2}{*}{ الاختبار } \\
\hline & & الانحرافي & التتوسط & الالانحرافيافي & المتوسط & & \\
\hline كبير & **Y1, 74r & $r, 1.9$ & $9,7 r$ & $r, \wedge \wedge 0$ & $r r, r V$ & 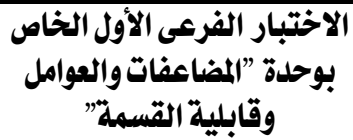 & 楊丰 \\
\hline كبير & **IY,AYO & $1,\{7 \xi$ & $r, \wedge T$ & $r, \cdot r_{0}$ & $11,9 v$ & الاختبار الفرعى الثانى" الخياس" & 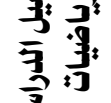 \\
\hline كبير, & **Yq, r & $r, \cdot \& r$ & Ir, & $r, 710$ & $r q, \cdot v$ & الاختبار & \\
\hline
\end{tabular}

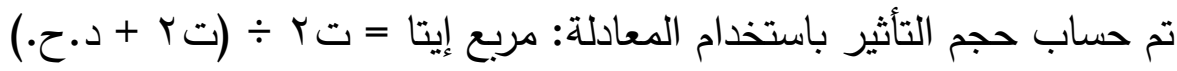

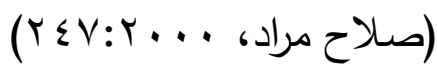

$$
\text { يتضح من الجدول (ع ( ) ما يأتي : }
$$

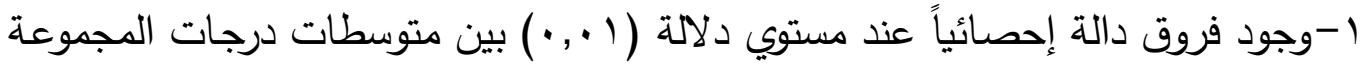

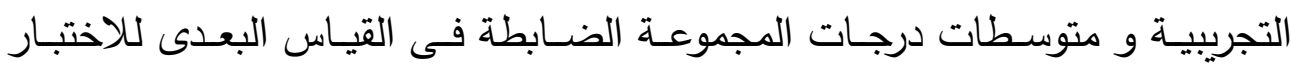

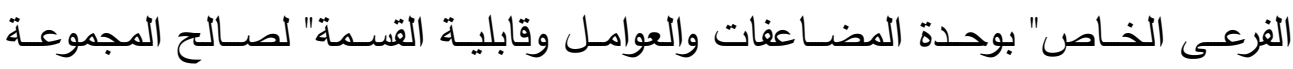


التجريبية، وكذا قيمة "ت" دالة إحصائياً عند مستوى ( ال. , ) لصالح القياس البعدي

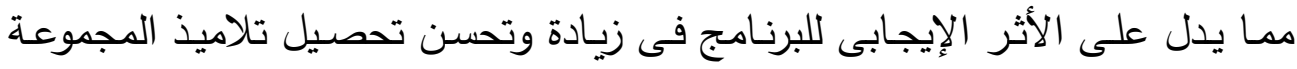
التجريبية على الاختبار الفرعى الخاص بـ" وحدة المضاعفات والعوامل وقابلية القسمة"

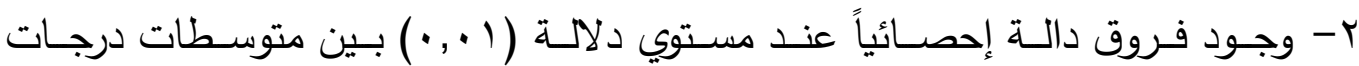

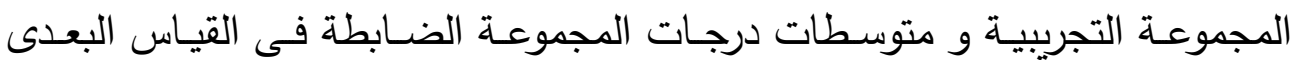

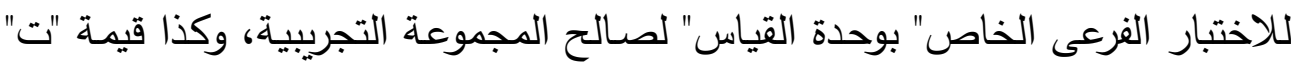

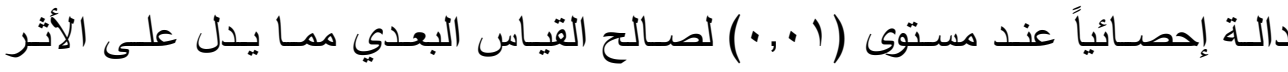

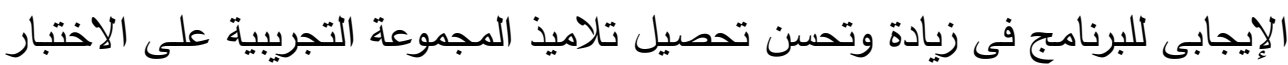

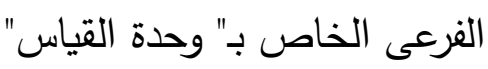
r-وجود فروق دالة إحصائياً عند مستوي دلالة (1 ب. . ·) بين متوسطات درجات المجموعة

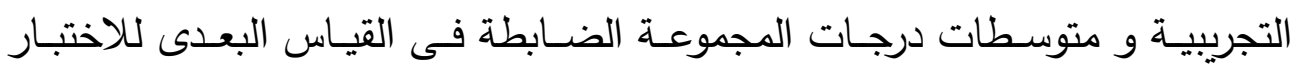
التحصيلى الكلى للرياضيات لصالح المجموعة التجريبية، وكذا قيمة "ت" دالة إحصائياً

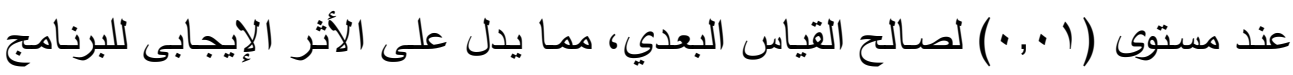

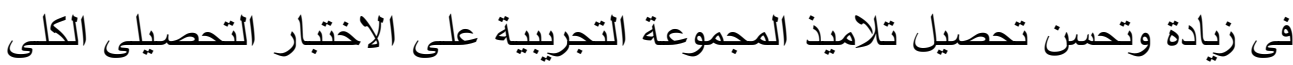
ل للرياضيات. ع -جاءت قيم حجم تأثير البرنامج التدريبي في تتمية كل (الاختبار الفرعى الخاص بـ"

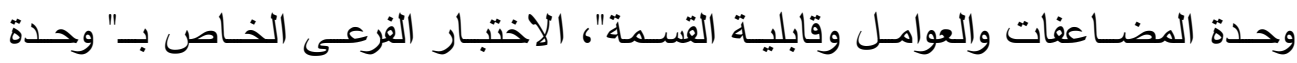

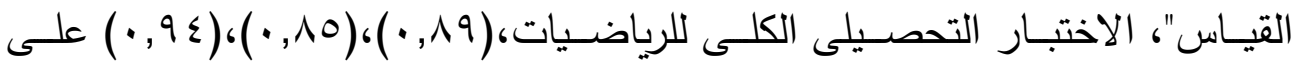

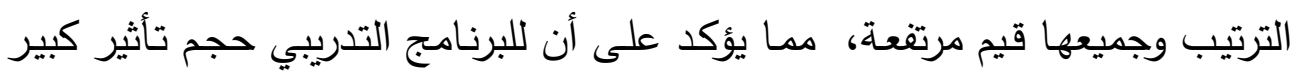

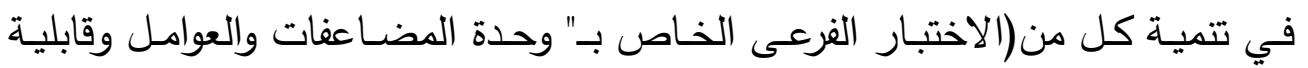
القسـة"، الاختبار الفرعى الخـاص بـ" وحدة القياس"، الاختبـار التحصيلى الكلى التى للرياضيات) لدى تلاميذ المجموعة التجريبية .

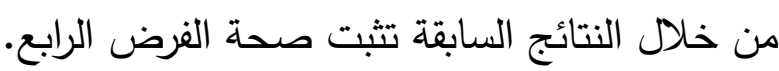

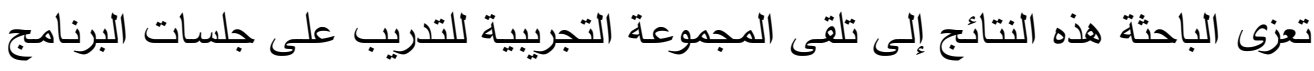

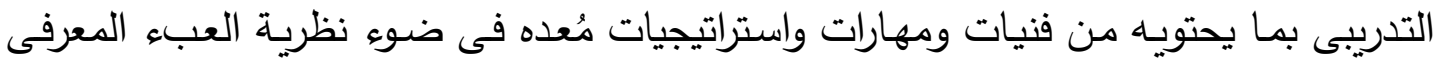

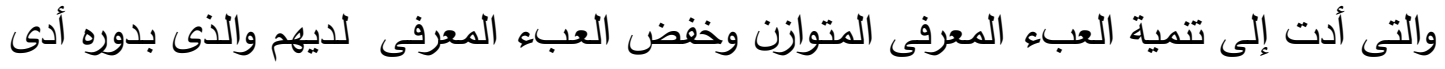

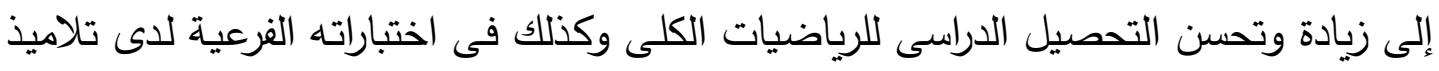
المجموعة التجريبية، بينما عدم تلقى المجموعة الضابطة للتدريب. 
اتفقـت نتـائج هـذا البحـث مـع نتـائج بعـض الدراسـات مـن حيـث فاعليـة الفنيـات والاستراتيجيات والمهارات المستخدمة لخفض صعوبات تعلم الرياضيات وتحسين التحصيل

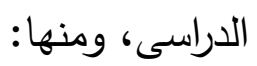

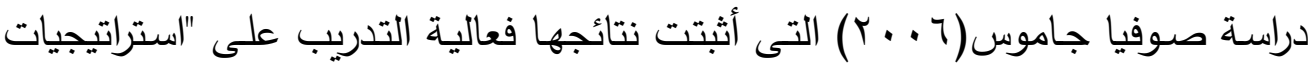
التتظيم الذاتى "فى تتمية مهارات حل المشكلة الحسابية لدى تلاميذ العينة التجريبية. دراسة(هشام بسيونى (Y T Y T) التى أكدت نتائجها فاعلية برنامج وسائط متعددة بواسطة

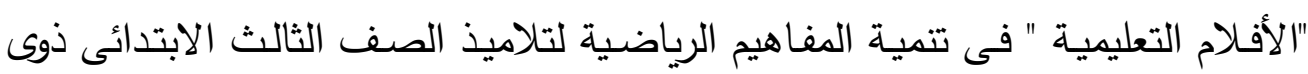

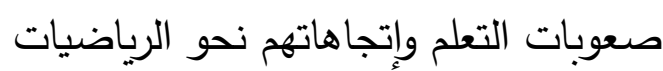

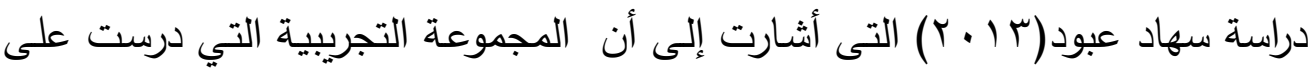

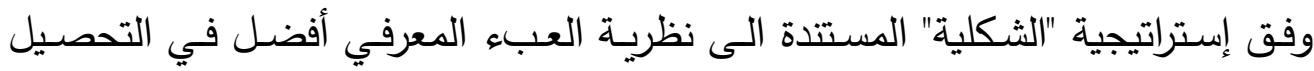

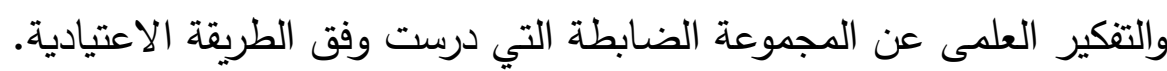

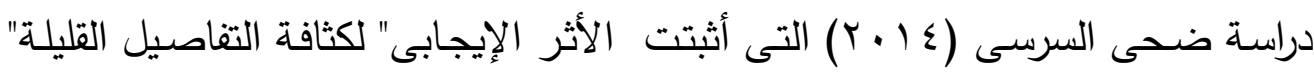

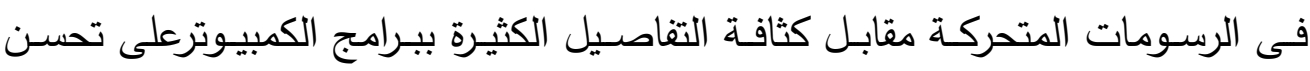
التحصيل المعرفى لمحتوى الرياضيات للى تلاميذ الصف الثانى بالمرحلـة الابتدائية

$$
\text { ذوى صعوبات تعلم الرياضيات. }
$$

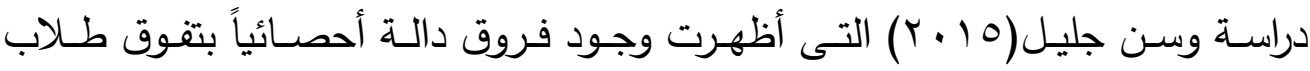
المجموعة التجريبية التى درست وفق استراتيجيات العبء المعرفى على المجموعـة الضـابطة فى الاختبار التحصيلى فى الكيمياء الحياتية واستبقاء المعلومات والتتوير العلىى والتكنولوجى لاى عينة من طلاب الجار الجامعة.

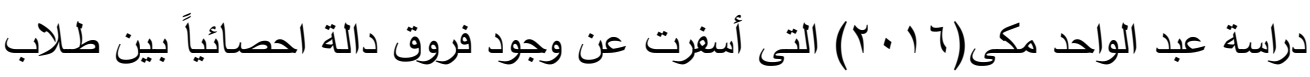

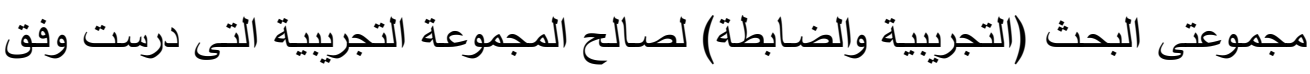
استراتيجيات العبء المعرفى فى الاختبار التحصيلى واختبار الذكاء المكانى البصرى.

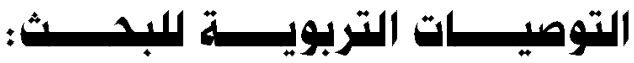

في ضوء إجراءات البحث الحالى وما توصلت إليه الباحثة من نتائج وما قدمته من تفسيرات، تم تقديم التوصيات التالية:

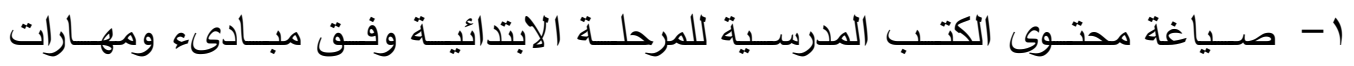
واستراتيجيات العبء المعرفى. 
r- تدرج عرض محتوى منهج الرياضيات بأسلوب شيق وبصورة مواقف مختصره تراكميه

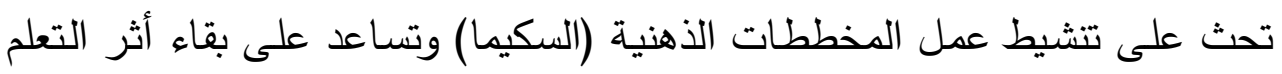
والاتوماتيكيه فى معالجة المعلومات.

r- تقليص محتوى المنهج الدراسي مما يوفر للمعلمين الوقت الكافى لتطبيق استراتيجيات

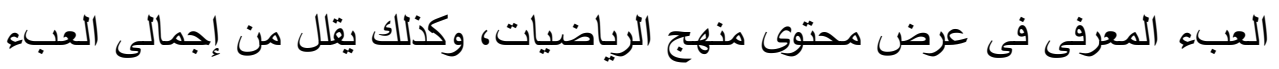

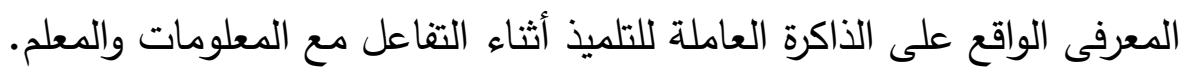
ع- تغيير أنــاط الامتحانـات التقليديـة لتناسب تطـوير المنهج وصـياغتها في صـورة مشكلات رياضية. ه- ضرورة إحداث تتسيق بين قسمى علم النفس التربوى والمناهج وطرق التدريس بكليات

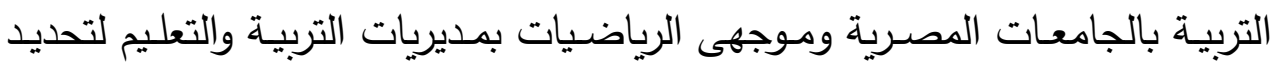

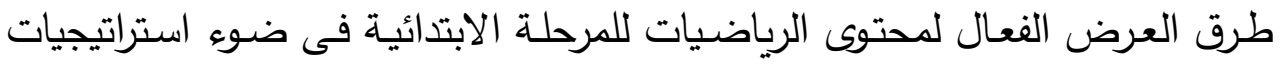

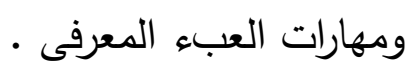

צ- حث طلاب التربية العملية على صياغة محتوى الدروس وفق مهارات واستراتيجيات

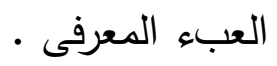

- V

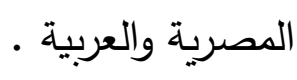

^- ضـرورة توعيـة مديرى المـارس الابتدائيـة بأهميـة تسهيل إجراءات تطبيق البحث العلمي على تلاميذ المرحلة الابتدائية. 9- عقد ورش عمل للمعلمين حول أسس برامج التكامل بين علاج صعوبات العمليات

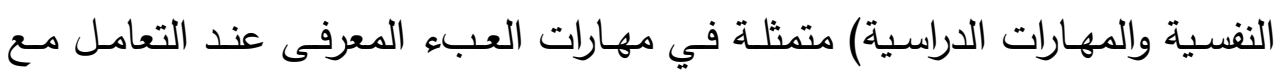
تلاميذ المرحلة الابتدائية من ذوى صعوبات التعلم. • ا-زيادة الحافز المادي والمعنوي للمعلمين الحاصلين على دورات تدريبية أو درجات

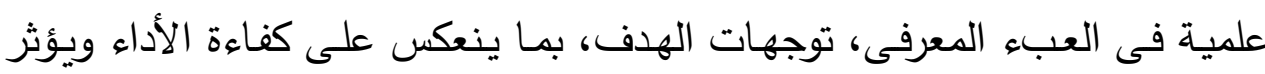
بإيجابية في العملية التعليمية. 1) حلها لتزويد معلم الرياضيات لنقاط ضعف الطفل وليس حل الواجب المنزلى من قبل أحد أفراد الأسرة لتحقيق التفوق المزيف لطفلهم. 
rاستغلال فرصـه تنزه الأسرة فى الحدائق أو الرحلات أو السوبر ماركت أو السوق

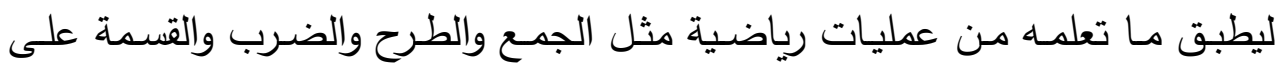
مواقف حياتيه.

rا-تثجيع الطفل على الصبر وتأجيل الإثباع والمثابرة في أدائه للمهمة المطلوبة منه. ؟ ا-إعطاء الطفل التدريب المركب بتقسيمه إلى أجزاء صغيرة مع التعزيز الفوري بعد كل التسبه جزه، على أن يتخلل ذلك فترات راحة قصيرة يُسمح له فيها بحرية الحركة.

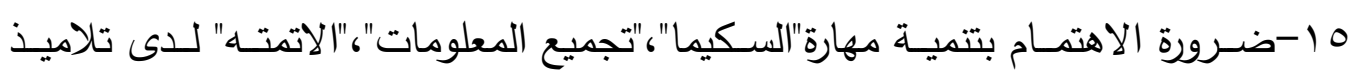

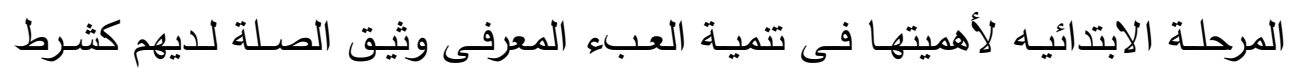

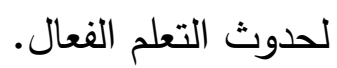

\section{بــــوث ودراسيـات مقترحسية:}

1- دراسة تتبعية للعينة التي طبق عليها البرنامج التدريبى الحالى، ومدى بقاء أثر

$$
\text { البرنامج بعد مرور فترات زمنية مختلفة. }
$$

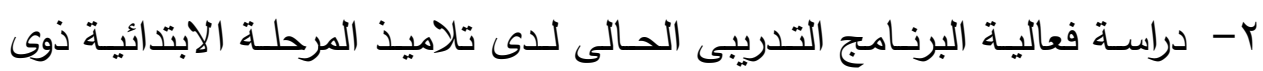

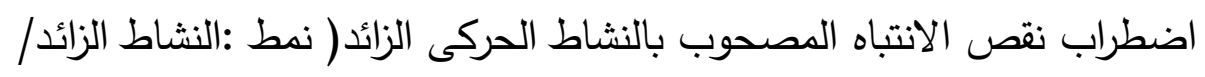

$$
\text { الاندفاعية). }
$$

r- بحث طرق اختزال العبء المعرفى الخارجى لدى تلاميذ المرحلة الاعدادية فى العى مقرر الهندسة فى ضوء مستويات متعددة من صعوبة المقرر. 


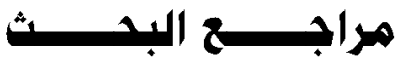

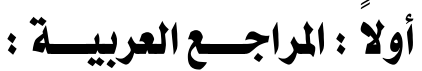

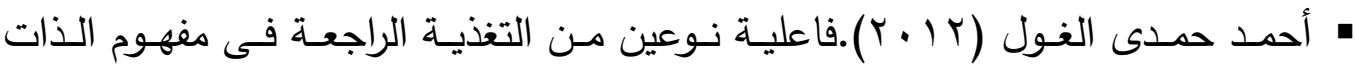
الأكاديمى للتلاميذ ذوى الصعوبات التعلم فى الرياضيات.رسالة ماجستير، كلية التربية

$$
\text { بالعريش، جامعة قناة السويس. }
$$

• السيد عبد الحميد سليمان(1 . . ץ).صعوبات التعلم النمائية.القاهرة:علم الكتب.

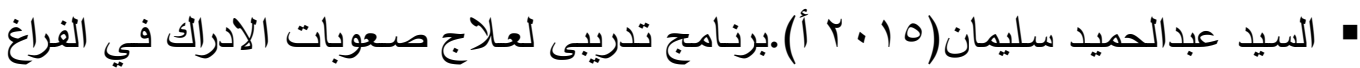

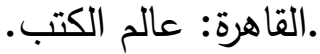

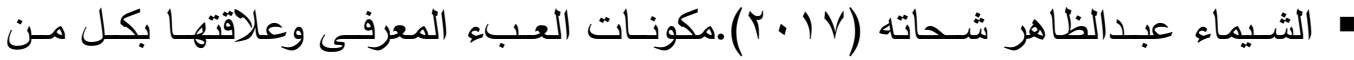
الأسـاليب المعرفيـة لــ(ريدنج) والتحصيل الدراسـى لطلبـة الصـف الأول الثانوى العـام .رسالة دكتوراه،كلية التربية، جامعة الزقازيق. • جمال عطية فايد(7 ( • (ب).صعوبات التعلم لاى الأطفال والراشدين.الإسكندرية: المكتبة

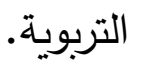

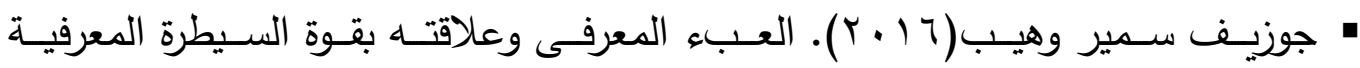
والتحصيل الدراسى لدى طلاب الجامعة. رسالة ماجستير،كليةالتربية،جامعة السويس.

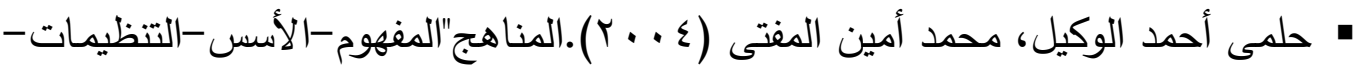
التطوير".القاهرة: الأنجلو المصرية.

• حلمى الفيل (10 ب).مقياس العبء المعرفى.القاهرة: مكتبة الأنجلو المصرية.

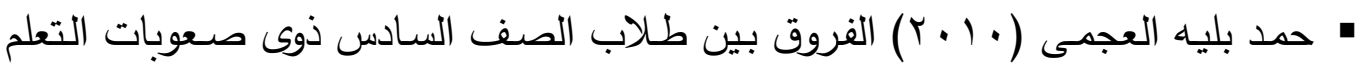
المدمجين وغير المدمجين في التوافق النفسي والتحصيل الدراسي،يلالمجلة المصـرية

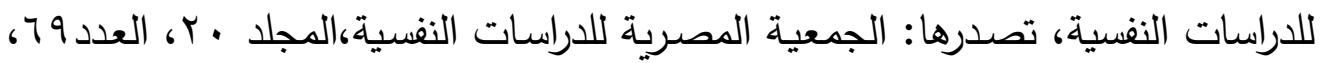

$$
\text { أكتوبر ، ص صن } 90
$$

- زينب عبد العليم بدوى(ع ( • ب). مقياس العبء المعرفى.القاهرة: دار الكتاب الحديث.

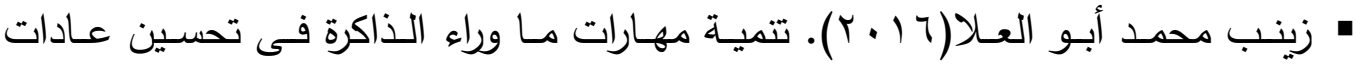
الاستذكار وفاعلية الذات لدى ذوى صعوبات التعلم فى مرحلة الطفولة المتأخرة.رسالة دكتوراه، كلية البنات، جامعة عين شمس. 


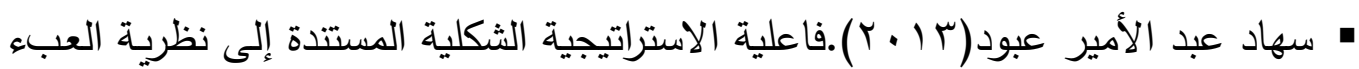

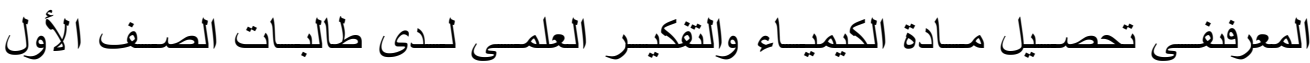

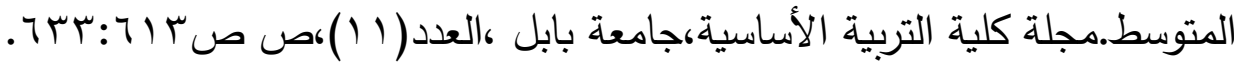

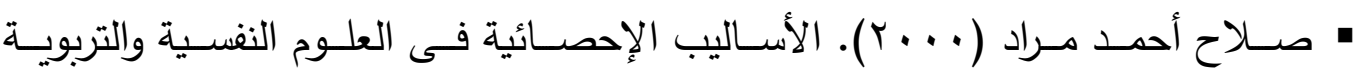
والاجتماعية. القاهرة، مكتبة الأنجلو المصرية.

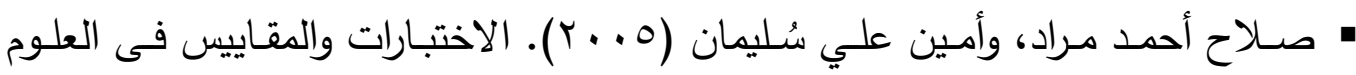
النفسية والتربوية خطوات إعدادها وخصائصها (طץ). القاهرة: دار الكتاب الحديث.

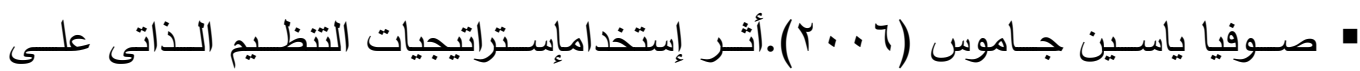

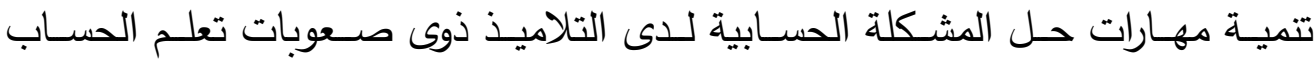

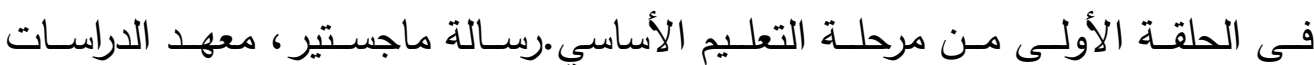

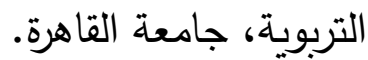

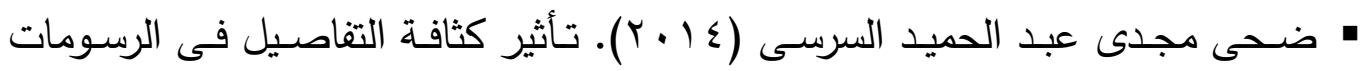

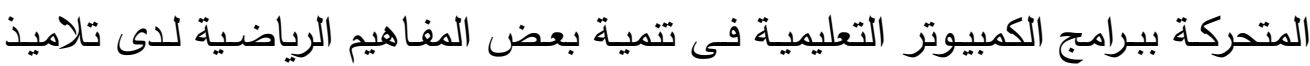

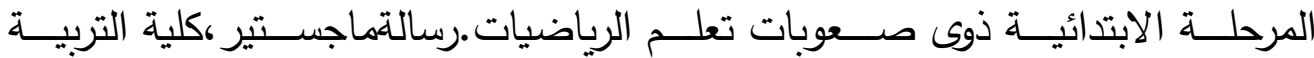
النوعية،جامعة عين شمس.

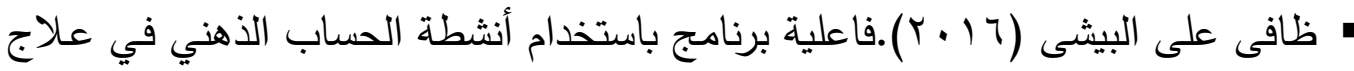

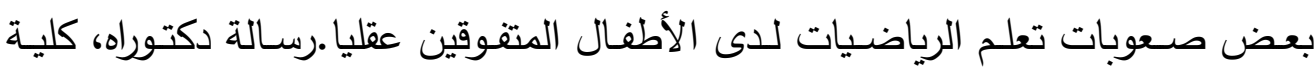
التربية، جامعة عين شمس.

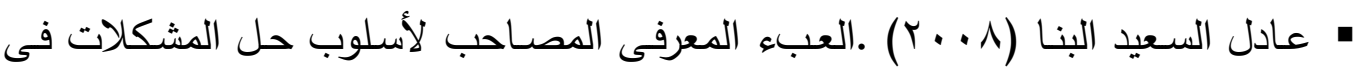

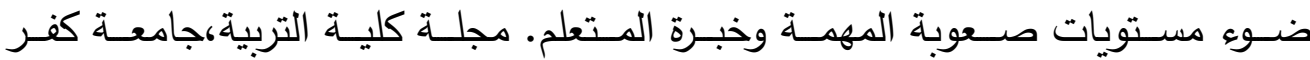

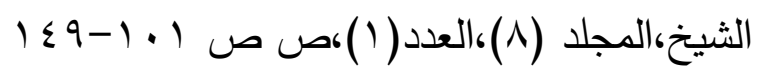

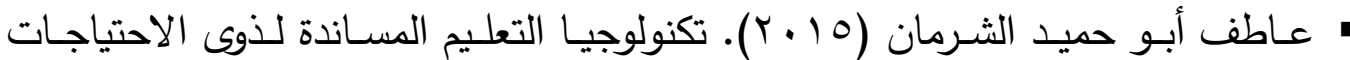
الخاصة.عمان:دار المسيرة للنشر والتوزيع. • عادل محمد العدل (T ( ب).التعلم الإكترونى وصعوبات التعلم.القاهرة: عالم الكتب.

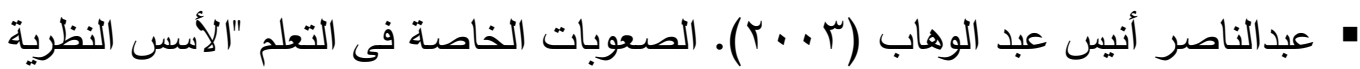
والتثخيصية".الإسكندرية:دار الوفاء. 


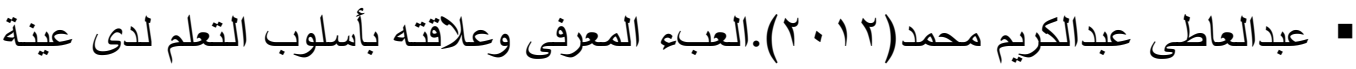

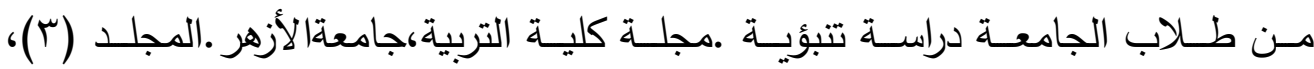

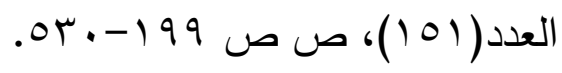

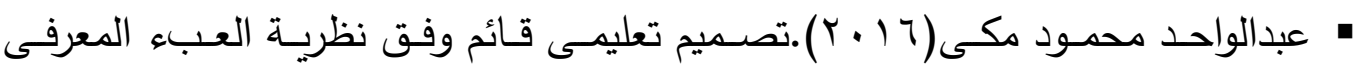

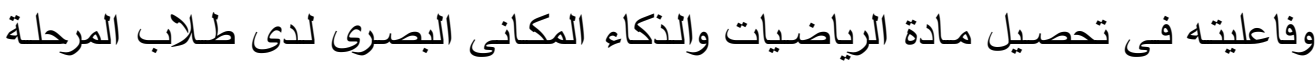

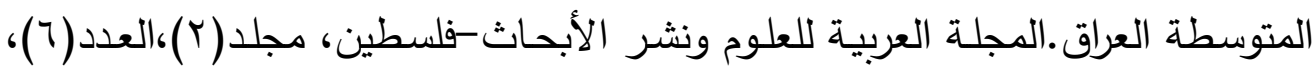

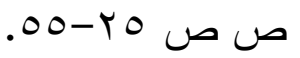

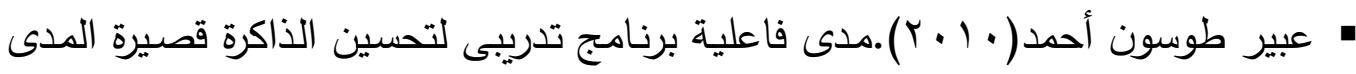

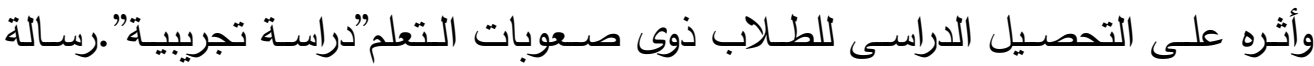
دكتوراه، كلية الآداب.جامعة المنيا.

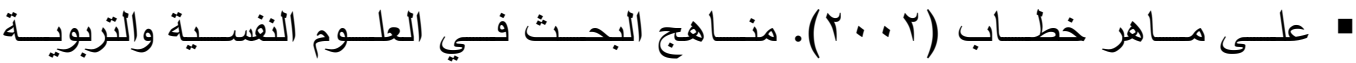
والاجتماعية.القاهرة: الدكتبة الأكاديمية.

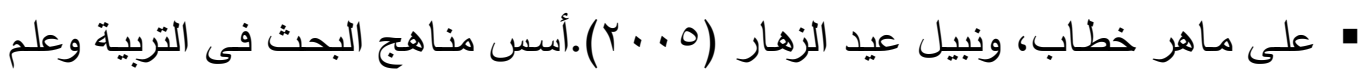
النفس. القاهرة: مكتبة عين شمس.

• على ماهر خطاب (1 . . ץ).القياس والتقويم فى العلوم النفسية والتربوية والاجتماعية ه (ط ملى) مزيدة ومنقحة. القاهرة: المكتبة الأكاديمية.

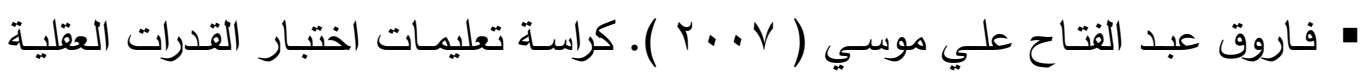
مستوي 9-1 اسنة .القاهرة: النهضة المصرية -

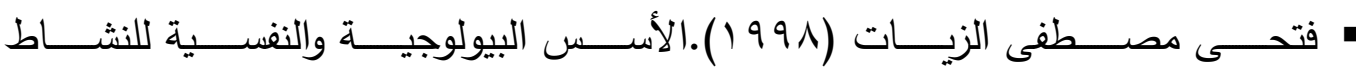
العقلالمعرفى.القاهة:دار النشر للجامعات.

• فتحى مصطفى الزيات (10 ب r). صعوبات التعلم :التوجهات الحديثة فى التثخيص والعلاج.القاهرة:مكتبة الأنجلو المصرية.

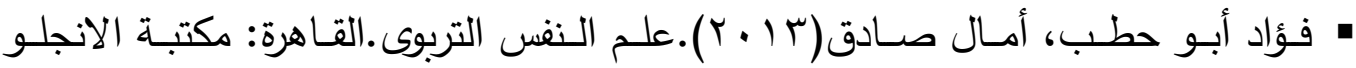

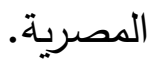

• قطـاع الكتب(9 . . ب).دليل المعلم (الرياضيات).جمهورية مصر العربية:وزارة التربيـة والتعليم. 
• محمد أمين المفتي(990 ()). قراءات في تعليم الرياضيات. القاهرة: مكتبـة الأنجلو

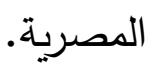

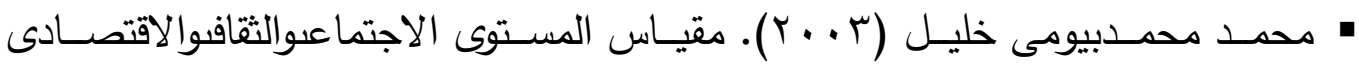
(المطور) للأسرة المصرية.القاهرة: دار قباء للطباعة والنشر .

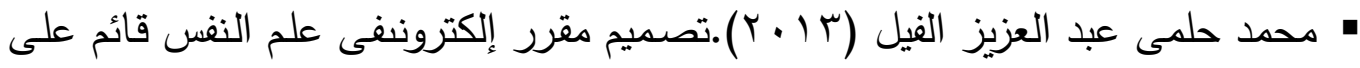

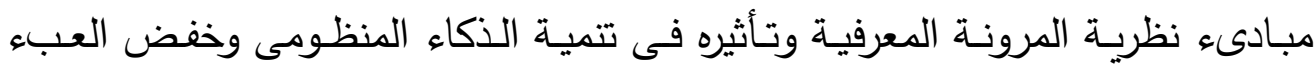
المعرفى لدى طلاب كلية التربية النوعية جامعة الإسكندرية.رسالة دكتوراه، كلية التربية

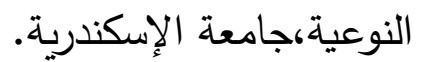

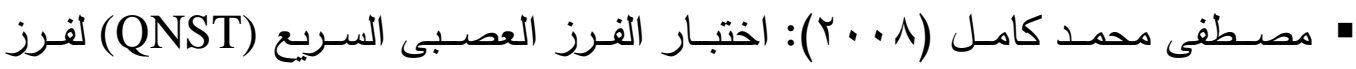
التلاميذ ذوى صعوبات التعـلم (ط؛). القاهرة: مكتبة الأنجلو المصرية. • نجلاء محمد فارس، عبدالرؤوف محمد إسماعيل(Y V • Y).التعليم الإلكترونى مستحدثات في النظرية والاستراتيجية.القاهرة: عالم الكتب. • نهلة عبدالرازق عبدالمجيد(Y ( ץ).فاعلية برنامج تدريبى مبنى على نموذج تريفنجر

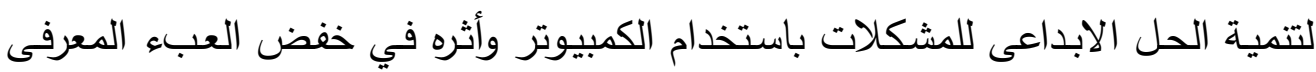
لاى عينة من طلاب كلية التربية. رسالة دكتوراهكلية التربية، جامعة أسيوط. • نهى فؤاد بخاطره(Y V Y Y).فاعلية برنامج قائم على استراتيجيات ماوراء المعرفة لتتمية المرونة المعرفية وخفض العبء المعرفى لاى تلاميذ المرحلة الأعدادية.رسالة دكتوراه،

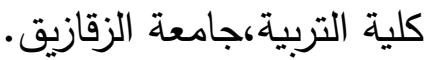

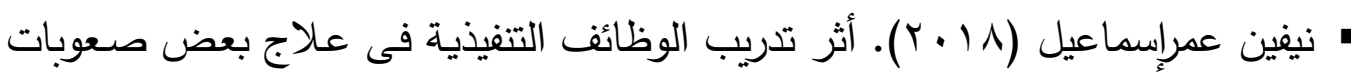
تعلم الرياضيات لدى الأطفال.رسالة ماجستير، كلية التربية، جامعة عين شمس.

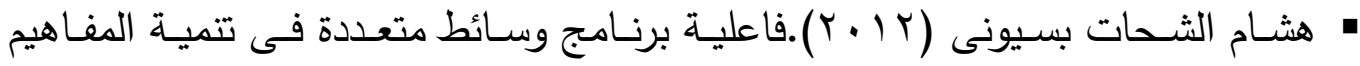
الرياضية للتلاميذ ذوى صعوبات التعلم بالحلقة الأولى من التعليم الأساسـوإتجاهاتهم نحو الرياضيات.رسالةدكتوراهمعهد الدراسات التربوية،جامعة القاهرة. 
- واثق عمر موسى التكريتى،جناز عبدالقادر أحمد (ب ا ـ ץ). العبء المعرفى لدى طلبة

المعهد التقننفى كركوك وعلاقتهـ بـبعض المتغيـرات .مجلـة جامعـة كركوك للدراسـات

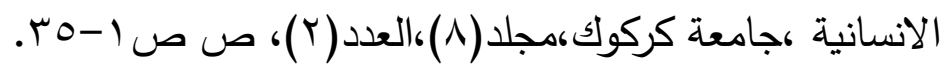

• وليم عبيـد ومحمـد المفتى وسـير إيليـا( . . . . ). تربويـات الرياضــيات. القاهـرة:

مكتبــة الأنجـلو المصريـة.

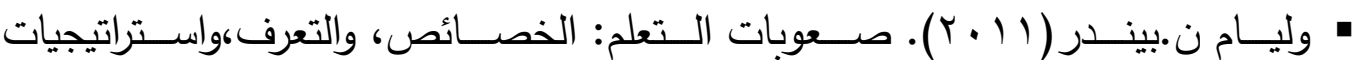

التدريس(ترجمـة: عبـدالرحمن سـيد سليمان،السـيد التهـامى،محمود محمـــ الطنطـاوى).

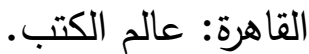

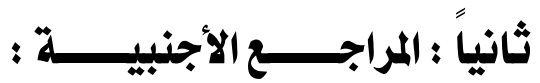

- Antonenko,P. \&Niederhauser, D. (2010).The Evidence of Leads on Cognitive Load and Learning in a Hypertext Environment. Journal of Computers in Human Behavior,26(1),PP 140-150.

- Dykem\& Engblade,A (2005). The Roles of Redundancy and Expertise in Group Decision-Making and Recall, Unpublished phD Thesis, Loyola University of Chicago.

- Jeffries,S. \&Everatt,J. ( 2004 ) : Working memory: Its role in dyslexia and other specific learning difficulties. Dyslexia :An International Journal of Research and Practice ,10,3,196-214

- Kalyuga, S.(2010).Scheme Acquisition and Sources of Cognitive Load, in Plass, J.; Moreno, R. \&Brunken, R.(Eds). Cognitive Load Theory. New York: CambridgeUniversity Press,pp 48-64.

- Lianears, G.W.(2002).Identification and Assessment of gifted Students with Learning Disabilities.Journal of Educational Psychology,44(2),115-124. 
- Leppink, J.; Pass, F., Van der Vleuten, C. p. M.; Van Gog, T.; \& Van Merrienboer, J. J. G. (2013). Development of an instrument for measuring different types of cognitive load .Behavioral Research. Vol.(45),pp.1058-1072.

- NASA- TLX. (2003).Computerized Version 2.0 for Task Load Index.Moffett field CA940435.Ames Research Center, Aerospace Human factor Research Division

- Olmstead , R. (2005) : Use of auditory and visual stimulation to improve cognitive abilities in learning disabled children. Journal of Neurotherapy , 9, 2, 49- 61.

- Shi-jie, Z. (2004):Working memory in learning disabled children. Chinese Journal of Clinical Psychology ,12 (3) , 313-317

- Swanson, H.L. ; Cochran, K.F.\&Ewers, C.A.(1990):Can learning disabilities be determined from working memory performance ?. Journal of Learning Disabilities,23,1,59-67.

- Sweller, J.,\&Chandler, P.(1991).Why Some Material is Difficult to Learn .Cognition and Instruction.12(1),185-233.

- Sweller,J. (2004). Instructional Design Consequence of an Analogy Between Evolution by Natural Selection and Human Cognitive Architecture.Instructional Science,32,pp.9-31.

- Terry (2006). Neurophysiological correlates of age-related changes in working memory capacity. Neuroscience Letters,392(12),p.p32-37 
- Vanloon-Hillen, N; VanGog, T\& Brand-Gruwel, S. (2012). Effects of Worked Examples in a Primary School Mathematics Curriculum. Interactive Learning Environments,20(1),89-99.

- Weigand,F. \&Hanze, M. (2009). Inducing Germane Load While Reducing Extraneous Load by Incrementally Fading - in Awork Example, Department of Psychology,12(4),46-67.

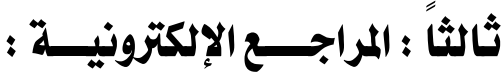

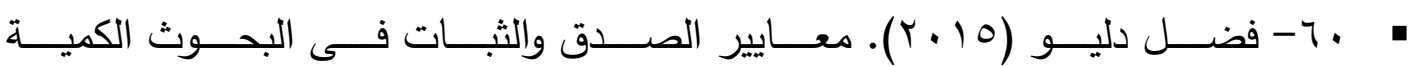

https:// badislounis.blogspot.com/2015/08/blog-1الكيفيــة.متاحفى

$$
\text { post_22.html?m=1 }
$$

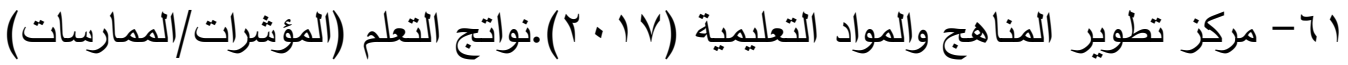

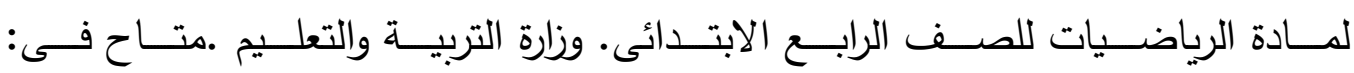
in 1/9/2017.https://moe.gov.eg/ccimd/index.html rآ- وسن ماهر جليل(10 1 ب). أثر التدريس لاوفق نظريـة العبء المعرفى فى تحصيل

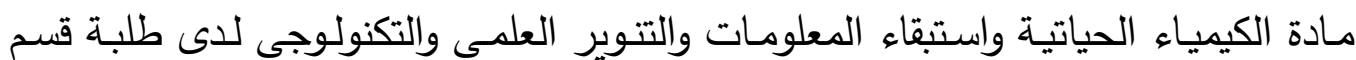

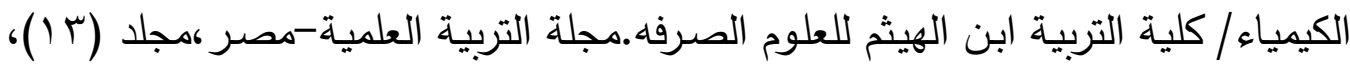

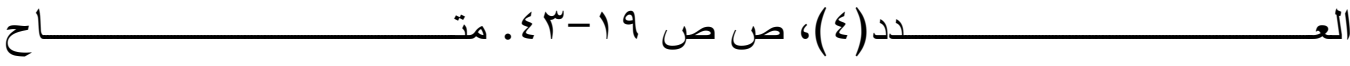

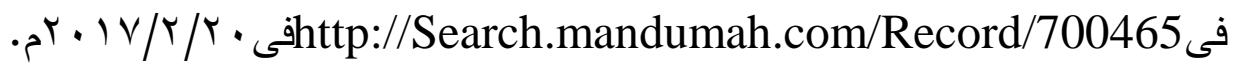

- 63. Jeffrey, M. \& Ian, M. (2015,September 17).Understanding Working Memory and Learning Disabilities.LD @ School.Retrieved from https://www.ldatschool.ca/ Understanding Working Memory and Learning Disabilities. 